\title{
Review
}

\section{A Learning-by-Doing Approach to Entrepreneurship Education: Evidence from a Short Intensive Online International Program}

\author{
Alessandra Colombelli (iD, Andrea Panelli and Francesco Serraino* \\ Department of Management and Production Engineering and Entrepreneurship and Innovation Centre (EIC), \\ Politecnico di Torino, Corso Duca degli Abruzzi, 24, 10129 Turin, Italy; alessandra.colombelli@polito.it (A.C.); \\ andrea.panelli@polito.it (A.P.) \\ * Correspondence: francesco.serraino@polito.it
}

Citation: Colombelli, Alessandra, Andrea Panelli, and Francesco Serraino. 2022. A Learning-by-Doing Approach to Entrepreneurship Education: Evidence from a Short Intensive Online International Program. Administrative Sciences 12 16. https://doi.org/10.3390/ admsci12010016

Received: 15 November 2021

Accepted: 14 January 2022

Published: 21 January 2022

Publisher's Note: MDPI stays neutral with regard to jurisdictional claims in published maps and institutional affiliations.

Copyright: (C) 2022 by the authors. Licensee MDPI, Basel, Switzerland. This article is an open access article distributed under the terms and conditions of the Creative Commons Attribution (CC BY) license (https:// creativecommons.org/licenses/by/ $4.0 /)$.

\begin{abstract}
Entrepreneurship is considered a key driver for economic growth. Therefore, more and more studies are investigating the role and effectiveness of entrepreneurship education. In this context, the present study is aimed at investigating the effectiveness of entrepreneurship programs, with a learning-by-doing approach, on the entrepreneurial intention, entrepreneurial characteristics (entrepreneurial attitude, entrepreneurial self-efficacy, entrepreneurial mindset, core self-evaluation) and entrepreneurial skills (creativity, financial literacy, marshaling of resources, planning, teamwork). The study has analyzed a short intensive online entrepreneurship program, which adopts a learningby-doing approach and targets students from different European technical universities, with different levels of education and different entrepreneurial backgrounds, giving them the opportunity to work on different types of projects. Pre- and post-course surveys were conducted in order to perform qualitative analyses on the effectiveness of the program. The results show that the entrepreneurial intention and perception of the entrepreneurial characteristics and skills of the students increased after participation in the program. In addition, our findings reveal that the program appears to be more effective for MSc students than for PhD ones and for students who had never attended any entrepreneurship program before, while there is no difference in the effectiveness of the program in terms of gender.
\end{abstract}

Keywords: entrepreneurship education; student entrepreneurship; learning-by-doing; entrepreneurial learning; entrepreneurial intention; entrepreneurial skills

\section{Introduction}

It is widely recognized that entrepreneurship plays a key role in fostering economic growth and job creation (Thurik and Wennekers 2004). In such a context, both policy makers and academics have recognized the importance of more commitment to entrepreneurship, even at the university level, to spread knowledge and best practices (European Commission 2012). For example, in 2012, the European Commission pointed out the need for more commitment to entrepreneurship and especially to entrepreneurship education (European Commission 2012).

Universities are considered a privileged place for the creation of new innovative enterprises and the diffusion of entrepreneurial skills and knowledge (Cassia and Colombelli 2008; Carree et al. 2014; Ricci et al. 2019). Universities, which are primary sources of cutting-edge knowledge, in fact, play an important role in training individuals who are able to acquire, transform, and exploit such knowledge (Zahra and George 2002; Colombelli et al. 2021a). Such individuals are often students who are able to apply their knowledge to have an impact on society through the creation of new innovative enterprises or spread them by entering the labor market (Larsson et al. 2017; Wenninger 2018). Building on this, scholars are dedicating more and more attention to the creation of enterprises by university students (Bergmann et al. 2016; Minola et al. 2016; Chiarello et al. 2021). 
Universities are paying attention to the creation of specific programs to increase awareness (Siegel and Wright 2015; Birtchnell et al. 2017), promote entrepreneurial propensity and mindsets among students and support the creation of new businesses (Hoppe 2015; Varano et al. 2018; Hahn et al. 2020). As a result, there has been an increase in the number of entrepreneurship programs offered to university students throughout the world (European Commission 2012; Ramos-Rodríguez et al. 2019).

From an academic perspective, understanding the effectiveness of these entrepreneurship programs is of paramount importance. In this direction, two strands related to entrepreneurship education can be identified in the literature. The first one focuses on the identification of the different approaches through which entrepreneurship education is taught (Vesper and Gartner 1997; Dana 2001; Matley 2006; McKeown et al. 2006). The second strand investigates the effectiveness of the different approaches (Charney and Libecap 2000; Henry 2004; Fayolle et al. 2006). Three main criteria have been identified to measure the effectiveness of entrepreneurial education programs and analyze in the empirical literature: the creation of a new enterprise (Charney and Libecap 2000; Rosa 2003; Henry 2004), academic performance (Hynes 1996; Vesper and Gartner 1997; Charney and Libecap 2000; Colombelli et al. 2021b) and psychological constructs (Peterman and Kennedy 2003; Rosa 2003; Veciana et al. 2005; Fayolle et al. 2006; Lee et al. 2006; Souitaris et al. 2007; Mwasalwiba 2010; Colombelli et al. 2022).

The findings of both streams reveal that the different approaches are all important and complementary (Dreisler et al. 2003; Pittaway and Cope 2007; Pittaway 2009). However, most studies state that more practice-oriented courses are more effective in improving an individual's entrepreneurial characteristics and skills than purely theoretical-oriented courses (Honig 2004; Rasmussen and Sørheim 2006; Pittaway and Cope 2007; Kassean et al. 2015). Furthermore, approaches focused on practical experience help to increase entrepreneurial intention (Kassean et al. 2015).

In line with these arguments, this study falls into the second strand of the literature by considering a short intensive online entrepreneurship program, which adopts a learning-bydoing approach and targets students from different European technical universities, with different levels of education and different entrepreneurial backgrounds, giving them the opportunities to work on different types of projects. A psychological construct approach is adopted in the study to analyze the effectiveness of such a program on the entrepreneurial intention, entrepreneurial characteristics (entrepreneurial attitude, entrepreneurial selfefficacy, entrepreneurial mindset, core self-evaluation) and entrepreneurial skills (creativity, financial literacy, marshaling of resources, planning, teamwork). The high heterogeneity that characterizes this program has allowed us to study the impact of entrepreneurship education from different perspectives. The paper thus contributes to the literature in many different respects. First, compared to most studies on learning-by-doing programs that focus on students with a specific level of education (Nabi et al. 2017), the aim of the present study is to investigate the effectiveness of an entrepreneurial program that was offered to students with different levels of education, that is, students from master's degree programs and doctoral students. Moreover, the program was offered to students from different areas of engineering (mechanical engineering, management engineering, computer engineering, etc.) and from different European technical universities. Furthermore, the course involved both students who were participating for the first time and students who had already participated in other entrepreneurial courses that adopted a learning-by-doing approach. We found it was possible to measure the effectiveness of the course in relation to the entrepreneurial background of the students. Finally, the students had the opportunity to work on entrepreneurial projects that were based on patented technologies developed in the academic context or on projects proposed by other students.

Building on this, this study aims to address the following research question:

- Does participation in a short intensive online entrepreneurial program with a learningby-doing approach increase the entrepreneurial intention, entrepreneurial characteristics (entrepreneurial attitude, entrepreneurial self-efficacy, entrepreneurial mindset, 
core self-evaluation) and entrepreneurial skills (creativity, financial literacy, marshaling of resources, planning, teamwork) of the participating students?

Furthermore, four sub-questions were added to explore whether a differential impact of the entrepreneurial program can be found depending on specific characteristics of the participating students:

a. Is the effect of the entrepreneurial program on the participants' entrepreneurial intention, characteristics and skills affected by gender?

b. Is the effect of the entrepreneurial program on the participants' entrepreneurial intention, characteristics and skills affected by their educational level?

c. Is the effect of the entrepreneurial program on the participants' entrepreneurial intention, characteristics and skills affected by their entrepreneurial background?

d. Is the effect of the entrepreneurial program on the participants' entrepreneurial intention, characteristics and skills affected by the type of project?

In order to assess the effectiveness of the program, we collected data through a survey that was administered to students before and after attending the program. The survey allowed us to collect the students' perceptions in relation to entrepreneurial intention and a set of entrepreneurial characteristics and skills. An improvement in the students' entrepreneurial intention, characteristics and skills has been observed from the pre- to the post-course responses. However, different effects emerged when the sample was broken down by educational level and the attendance of other entrepreneurship courses.

\section{Literature Review}

Scholars are paying more and more attention to entrepreneurship education and to the approaches used to teach entrepreneurship, with the aim of understanding university mechanisms to facilitate student entrepreneurship (Wright et al. 2017). According to previous works, the approaches used in entrepreneurial education can be divided into four teaching models: "about", "for", "through" and "embedded" (Gibb 2002; Handscombe et al. 2007; Pittaway and Cope 2007; Pittaway 2009).

The "about" model uses a traditional teaching approach. Its purpose is to transfer entrepreneurial knowledge and increase student awareness through theorical lessons (Pittaway and Hannon 2008). The second model, "for", is aimed at allowing students to acquire key skills and competencies through their involvement in activities and projects (McMullan and Long 1987; Vesper and McMullen 1988; Solomon et al. 2002). This model includes several approaches, such as the experiential approach. The experiential approach is a typical example of the "for" type of model, the aim of which is to make people acquire skills in view of a future entrepreneurial experience through practices (Gibb 2002). The third model, "through", requires students to practice entrepreneurship under controlled conditions (Hills 1988; Truell et al. 1998). Finally, the "embedded" model involves the inclusion of entrepreneurial content in courses focused on other disciplines (Solomon et al. 2002; Kuratko 2005; Handscombe et al. 2007). Thus, it aims to increase the entrepreneurial awareness of students in a specific domain. Of the four models outlined in the literature, the two primarily practice-oriented models are the "for" model and the "through" model. The "for" model is, in particular, aimed at developing entrepreneurial behaviors, such as opportunity seeking, and at increasing entrepreneurial skills. The aim of the "through" model is to involve students in "real-world" activities so that they can identify with the role of the entrepreneur and gain entrepreneurial experience. These two models are slightly different, although they both focus on the same aspect, the acquisition of skills and experience.

Several studies in the literature have shown that models that adopt a practice-oriented approach are more effective than theoretical models. According to Rae and Carswell (2000), entrepreneurship programs that adopt a learning-by-doing approach are more effective in improving the development of the entrepreneurial skills of students.

Specific measurement criteria are used to define the effectiveness of Entrepreneurship Education programs. The most widely used criterion in the literature involves investigating 
the number of students who start an enterprise after participating in an entrepreneurship program. Several studies agree on how entrepreneurship courses are closely related to the formation of new enterprises (Charney and Libecap 2000; Rosa 2003; Henry 2004; Lyons and Zhang 2018). The second criterion generally adopted by researchers is related to the academic performance of students. According to several researchers, the evaluations obtained in university exams and the final graduation mark are useful criteria to immediately assess the effects generated by participation in an entrepreneurship course (Hynes 1996; Vesper and Gartner 1997; Charney and Libecap 2000). The third criterion involves psychological constructs. Thus, to evaluate the effectiveness of an entrepreneurship program, it is possible to analyze the changes in the psychological constructs of students, such as entrepreneurial intention, entrepreneurial characteristics, and entrepreneurial skills (Peterman and Kennedy 2003; Rosa 2003; Veciana et al. 2005; Fayolle et al. 2006; Lee et al. 2006; Souitaris et al. 2007; Colombelli et al. 2022).

The empirical literature has provided evidence on the different models and their effectiveness. For example, Barr et al. (2009) analyzed a practice-oriented course based on "for" and "through" models. Barr and colleagues, through their experience of over ten years of TEC - an entrepreneurship course for students and researchers-identified the main characteristics that should be present in an entrepreneurship course that adopts a learningby-doing approach. They identified four elements: reality, intensity, interdisciplinarity and interactivity. The program analyzed by Barr et al. (2009) was offered to master's degree, PhD and MBA students from different universities. These students were offered a two-semester course during which they worked on technologies from either the university technology transfer office or from the R\&D departments of various companies. The main objective of the TEC program is to increase students' skills in technological entrepreneurship. The results of the study conducted by Barr et al. show that the program enabled students to acquire the necessary skills to recognize and understand entrepreneurial market opportunities.

Thursby et al. (2009) showed, in their study, that the multidisciplinary nature of a team is a key element for entrepreneurship programs that adopt a learning-by-doing approach. Thursby et al. (2009) conducted a study on an entrepreneurship program that had the aim to transfer a multidisciplinary perspective. According to Thursby and colleagues, such a perspective is necessary to succeed in innovation-related careers and to transfer the results of academic research to the market. The program was offered to $\mathrm{PhD}$ students in science and engineering, to law students and to MBA students. They conducted analyses, through a pre- and post-course survey, to assess the effectiveness of this program. The results of the analyses show an improvement in the students' ability to identify the market viability of a technology, identify the resources needed to succeed in a particular industry, identify business opportunities and assess the opportunities and threats of the competitive environment.

The studies by Barr et al. (2009) and Thursby et al. (2009) are literature examples that demonstrate that entrepreneurship education programs which adopt a learning-by-doing approach are effective in improving the entrepreneurial characteristics and skills of students and in encouraging the start of an entrepreneurial career. There are several studies in the literature that demonstrate how such programs generate a positive effect on entrepreneurial intention (Souitaris et al. 2007; Athayde 2009; Sánchez 2011, 2013; Martin et al. 2013; Walter et al. 2013; Bae et al. 2014; Zhang et al. 2014; Gielnik et al. 2015; Shahab et al. 2019), entrepreneurial characteristics (Fayolle et al. 2006; Souitaris et al. 2007; Wilson et al. 2007; Sánchez 2011; Fayolle and Gailly 2015; Duval-Couetil et al. 2021) and entrepreneurial skills (Wilson et al. 2007; Athayde 2009; Morris et al. 2013; Sánchez 2013; Duval-Couetil 2013; Shahab et al. 2019). 
However, it is necessary to draw attention to the characteristics of the entrepreneurship programs analyzed in the literature. Despite the studies by Barr et al. (2009) and Thursby et al. (2009), the literature review by Nabi et al. (2017) showed that most of the analyzed courses were designed for students of a specific educational level (BSc, MSc, $\mathrm{PhD}$, etc.) and students from a specific field of study, generally related to management and business. As also shown by the studies of Barr et al. (2009) and Thursby et al. (2009), such programs may last several months, sometimes even more than one academic semester. Moreover, such programs may involve entrepreneurial projects of the same type, such as projects based on a technology developed in the academic field, in the same program.

It appears that some aspects of the effectiveness of entrepreneurship programs that adopt a learning-by-doing approach are still under-explored. It could be interesting to investigate the effectiveness of such programs by involving students who have different levels of education. A second interesting aspect concerns the type of entrepreneurial project on which students work during these programs. It could be useful to investigate the effectiveness of such projects by including ones with different characteristics within the same program, e.g., projects based on technology developed in academia and projects proposed by students. A third element that could influence the effect of learning-by-doing programs on the entrepreneurial characteristics of students concerns the duration of these programs. Although the effectiveness of long-term programs has already been analyzed, to our best knowledge, the positive effect of intensive, short-term programs has yet to be proved. A fourth characteristic concerns the way in which the activities were carried out. In fact, all the activities of the program analyzed were carried out online, whereas in general a mode that allows activities to be carried out in person is preferred for such programs. Finally, an aspect that could further influence the impact of such programs is the entrepreneurial background of the students. It could be useful to understand whether the learning-by-doing approach is effective for students who have previous experience in such programs or for students who are participating for the first time.

The study presented in this article is aimed at investigating these under-researched aspects. Consequently, it focuses on the effectiveness of a learning-by-doing entrepreneurship program on the entrepreneurial intention, entrepreneurial characteristics (entrepreneurial attitude, entrepreneurial self-efficacy, entrepreneurial mindset, core self-evaluation) and entrepreneurial skills (creativity, financial literacy, marshaling of resources, planning, teamwork) of students. We have measured this effectiveness in relation to the level of education (MSc or PhD), the level of the entrepreneurial background, gender, and the type of entrepreneurial project on which the students have worked (patented technology or idea proposed by the students).

\section{Methodology}

\subsection{Program Description}

The program considered in this study is CAST, i.e., an entrepreneurship school for start-up creation organized by the Entrepreneurship and Innovation Center (EIC) of the Politecnico di Torino. CAST is a short intensive online entrepreneurship program that adopts a learning-by-doing approach. CAST targets students from different European technical universities, with different levels of education and different entrepreneurial backgrounds, giving them the opportunity to work on different types of projects. CAST is a program in which the participants have the opportunity to attend lectures and workshops on how to turn an idea into a profitable business. The main goal of the program is to involve students in the development of an entrepreneurial project by providing them with theoretical content and giving them the opportunity to work with a practice-oriented approach. 
The course is offered to students enrolled in master's degrees and doctoral courses from the partner universities of Unite!, ${ }^{1}$ a network that includes seven European technical universities: the Politecnico di Torino, the Technical University of Darmstadt, Aalto University, Grenoble INP Graduate school of Engineering and Management, KTH Royal Institute of Technology, Universidade de Lisboa and Universitat Politècnica de Catalunya.

The students who participated in the first edition had the opportunity to work on entrepreneurial projects based on technologies patented by the Politecnico di Torino or on entrepreneurial ideas proposed by other students. Specifically, the students worked on 4 patented technologies from Politecnico di Torino and 2 business ideas presented by students.

A total of 39 students were assigned to a specific project, on the basis of their preferences and skills, to form 6 teams of 6 or 7 people each. Moreover, the gender, background level and educational level of the members were taken into account in the creation of the teams. In this way, it was possible to organize multidisciplinary and highly motivated teams to tackle the course. As far as patented technologies are concerned, one or two inventors were involved in the teamwork, due to their profound knowledge of the technology, thus facilitating the transfer of know-how to the other members of the team. Similarly, the founders of the two entrepreneurial ideas proposed by students were involved in the teamwork. In addition to the features described so far, a final one deserves special mention: the participants were selected considering both students with previous experience in entrepreneurship programs that had adopted a practice-oriented approach and students involved in a program of this type for the first time.

In short, with respect to the previous courses on entrepreneurship education and learning-by-doing approaches (Barr et al. 2009; Thursby et al. 2009), the CAST program presents certain features that make it unique and interesting for potential research developments in the field of entrepreneurship education. The features that distinguish the program under investigation concern the following characteristics:

1. Duration: The program lasts a few weeks;

2. Intensity: All the activities are carried out day-by-day by the participants, in a short amount of days;

3. Online: Activities are carried out remotely;

4. Academic background: Students from different areas of engineering are involved;

5. University: The participants come from European technical universities belonging to the Unite! network;

6. Education level: The program involves both Master's and PhD students;

7. Support offered by Inventors and Founders: The inventors of technologies and founders of entrepreneurial ideas are involved in the development of the projects;

8. Entrepreneurial background: The participants should be quite heterogeneous, in terms of previous experience related to participation in entrepreneurship programs;

9. Entrepreneurial project: The participants have the opportunity to work on either patented academic technologies or ideas proposed by students.

The first edition, held in September 2021, lasted three weeks and it involved four intensive sessions per week, for a total of 12 sessions of three hours each.

Different types of activities, involving speakers from prestigious American universities, such as UC Berkeley and Hass School of Business, as well as from the Politecnico di Torino, were conducted during these sessions. The sessions were composed of both theorical lessons and workshops. During the theorical lessons, students learned concepts that would be useful for the development of an entrepreneurial project. During the workshops, students had the opportunity to learn by interacting in a participative way. Mentoring and team work sessions were also provided. Each team had the opportunity, during the mentoring sessions, to interact with experienced mentors and discuss the developments, difficulties and bottlenecks that emerged throughout the project. Each team worked, during the mentoring sessions, with the support of a tutor, on the different development phases of the project. In addition, the program also proposed "game" activities. During these 
activities, students had the opportunity to learn important entrepreneurial concepts such as scheduling tasks and pitching.

The program ended with a "demo day", during which the teams had the opportunity to present their entrepreneurial project in front of a panel of experts in the field of startup financing: business angels, venture capitalists and industry fellows, who had been involved in the project and had given useful feedback to the teams.

\subsection{Variables}

The aim of this study was to measure and evaluate the qualitative effectiveness of an entrepreneurial program that adopted a learning-by-doing approach on the entrepreneurial intention, entrepreneurial characteristics (entrepreneurial attitude, entrepreneurial selfefficacy, entrepreneurial mindset, core self-evaluation) and entrepreneurial skills (creativity, financial literacy, marshaling of resources, planning, teamwork) of the students who participated. We considered 10 entrepreneurial dimensions and measured the pre-program and the post-program values for each dimension. Of the 10 dimensions, one is entrepreneurial intention, while the remaining 9 relate to entrepreneurial characteristics and entrepreneurial skills, as can be seen in Table 1. We collected data by means of a survey that had been administered to all the students before the start of the program and after its conclusion.

As only one edition of CAST has been carried out, we built our analysis on a small sample of 34 students. Moreover, a control sample was not available, to compare the possible effect of CAST on other students who did not take part in it. In this vein, results are shown and discussed using a qualitative approach. However, we also conducted statistical tests. More precisely, $t$-tests were performed to compare the mean of each entrepreneurial variable in the pre-course to the mean of the same variable in the post-course for the whole sample and in relation to gender, educational level, entrepreneurial background and type of entrepreneurial project. The results of the $t$-tests are useful to strengthen the results of our qualitative analyses. Unfortunately, the small sample size does not allow to approximate the distribution of the data as a normal distribution, thus limiting the reliability of the results. For the sake of completeness, we report the results of the $t$-tests in Appendix A. However, these results must be interpreted with caution due to the reasons explained above.

Table 1. Domain and description of the 10 entrepreneurial variables.

\begin{tabular}{|c|c|c|}
\hline Domain & Variable & Description \\
\hline $\begin{array}{l}\text { Entrepreneurial } \\
\text { Intention }\end{array}$ & $\begin{array}{l}\text { Entrepreneurial } \\
\text { Intention }\end{array}$ & $\begin{array}{l}\text { This represents the conscious state of mind } \\
\text { that precedes action and directs attention } \\
\text { toward entrepreneurial behaviors, such as } \\
\text { starting a new venture and becoming an } \\
\text { entrepreneur (Moriano et al. 2012) }\end{array}$ \\
\hline \multirow{4}{*}{$\begin{array}{l}\text { Entrepreneurial } \\
\text { characteristics }\end{array}$} & $\begin{array}{c}\text { Entrepreneurial } \\
\text { Attitude }\end{array}$ & $\begin{array}{l}\text { This refers to the degree to which an } \\
\text { individual makes a positive or negative } \\
\text { evaluation of themselves as being an } \\
\text { entrepreneur (Linán and Chen 2009) }\end{array}$ \\
\hline & $\begin{array}{l}\text { Entrepreneurial } \\
\text { Self-Efficacy }\end{array}$ & $\begin{array}{l}\text { This measures the confidence of an } \\
\text { individual in their entrepreneurial skills } \\
\text { (Boyd and Vozikis 1994; Chen et al. 1998) }\end{array}$ \\
\hline & $\begin{array}{c}\text { Entrepreneurial } \\
\text { Mindset }\end{array}$ & $\begin{array}{l}\text { This captures an individual's sense of } \\
\text { initiative and attitude toward challenges, } \\
\text { perseverance and determination to complete } \\
\text { challenging tasks (Moberg et al. 2014) }\end{array}$ \\
\hline & Core self-evaluation & $\begin{array}{l}\text { This measures an individual's attitude } \\
\text { toward their ability to successfully perform } \\
\text { various activities and tasks (Judge et al. 2003) }\end{array}$ \\
\hline
\end{tabular}


Table 1. Cont.

\begin{tabular}{|c|c|c|}
\hline Domain & Variable & Description \\
\hline \multirow{5}{*}{ Entrepreneurial skills } & Creativity & $\begin{array}{l}\text { This is the ability to think in new and } \\
\text { imaginative ways, which is crucial for a } \\
\text { person to identify and discover new } \\
\text { entrepreneurial opportunities (Kirzner 1997; } \\
\text { McGee et al. 2009; Foss and Klein 2012) }\end{array}$ \\
\hline & Financial Literacy & $\begin{array}{l}\text { This represents the ability to understand } \\
\text { financial statements and budgets. Oggero } \\
\text { et al. (2019) show how this ability is } \\
\text { positively and significantly correlated with } \\
\text { the probability of being an entrepreneur }\end{array}$ \\
\hline & $\begin{array}{l}\text { Marshaling of } \\
\text { Resources }\end{array}$ & $\begin{array}{c}\text { This is the ability to assemble and organize } \\
\text { resources to exploit an entrepreneurial } \\
\text { opportunity (Foss and Klein 2012) }\end{array}$ \\
\hline & Planning & $\begin{array}{c}\text { This refers to the ability to plan and structure } \\
\text { tasks (Matthews and Scott 1995; McGrath } \\
\text { and MacMillan 2000; Delmar and Shane } \\
\text { 2003) }\end{array}$ \\
\hline & Teamwork & $\begin{array}{l}\text { This is the ability to achieve goals through } \\
\text { collaboration, as well as to build effective } \\
\text { relationships with others (West 2003) }\end{array}$ \\
\hline
\end{tabular}

We included between three and seven questions (items) in the survey for each of the ten dimensions. All the scales used in the analysis had been validated in previous studies. The adopted entrepreneurial intention and entrepreneurial attitude scales had both been developed by Linán and Chen (2009). The scale we applied for entrepreneurial self-efficacy has already been adopted in several studies (Chen et al. 1998; George and Zhou 2001; Zhao et al. 2005). Finally, we used the scales developed and validated by Moberg et al. (2014) for the remaining seven variables.

We used a 7-level Likert scale for each item. In most cases, students were asked about their level of agreement with the proposed statements: "Please indicate your level of agreement with the following statements", in which case the scale ranged from $1=$ strongly disagree to $7=$ strongly agree. In the case of entrepreneurial self-efficacy, the students were asked about their level of competence in relation to the proposed tasks: "Please indicate your level of competence in performing the following tasks", in which case the scale ranged from 1 = very low competence to 7 = very high competence.

\subsection{Sample}

As previously stated, we collected the data used for the analysis through a survey administered to the participants before the start of the program and immediately after the end. We carried out analyses on the impact of the program using only data from the students who responded to both surveys. The response rate was $87 \%$; thus, 34 students out of 39 participants responded.

As shown in Table 2, males represent $61.8 \%$ of the sample, while females constitute $38.2 \%$. In Table 2, it is also possible to observe the distribution of the students by university. Most participants are affiliated with the Politecnico di Torino $(82.4 \%)$, while $11.8 \%$ is from the Universidade de Lisboa. Finally, 2.9\% of the sample is from the Aalto University and $2.9 \%$ is from KTH Royal Institute of Technology. In addition, Table 2 shows the breakdown of the students by academic background. Management engineering is the most represented background (32.4\%). Computer engineering and biomedical engineering degrees are represented by $11.8 \%$ of the students, while $8.8 \%$ has a background in aerospace engineering and mechanical engineering. As far as the educational level is concerned, there 
is a prevalence of students attending a Master of Science degree course (67.6\%), while the remaining part is composed of $\mathrm{PhD}$ students (32.4\%).

The 34 students in the sample had the opportunity to work on either technologies patented by the Politecnico di Torino or on ideas proposed by other students. Table 2 shows that $67.6 \%$ of the students in the sample worked on a technology owned by the Politecnico di Torino, while the rest of the sample worked on an entrepreneurial idea proposed by other students. As far as the participation of inventors is concerned, each team had at least one inventor of a technology among its members. In fact, $14.7 \%$ of the students of the sample were also inventors of the technologies involved in the program.

Finally, Table 2 also shows the distribution of the students with previous experiences in entrepreneurship courses. Half of the participants had attended other entrepreneurship courses that had adopted a practice-oriented approach before participating in the program, while it was the first experience in this type of course for the other half of the participants.

Table 2. Distribution of students by the following variables: gender, university, education level, type of project, inventor and non-inventor and entrepreneurial background.

\begin{tabular}{|c|c|c|}
\hline Variable & Value & Percentage of the Sample \\
\hline \multirow[b]{2}{*}{ Gender } & Male & $61.8 \%$ \\
\hline & Female & $38.2 \%$ \\
\hline \multirow{4}{*}{ University } & Politecnico di Torino & $82.4 \%$ \\
\hline & Universidade de Lisboa & $11.8 \%$ \\
\hline & Aalto University & $2.9 \%$ \\
\hline & $\begin{array}{c}\text { KTH Royal Institute of } \\
\text { Technology }\end{array}$ & $2.9 \%$ \\
\hline \multirow{11}{*}{ Academic background } & Management Engineering & $32.4 \%$ \\
\hline & Computer Engineering & $11.8 \%$ \\
\hline & Biomedical Engineering & $11.8 \%$ \\
\hline & Aerospace Engineering & $8.8 \%$ \\
\hline & Mechanical Engineering & $8.8 \%$ \\
\hline & Mechatronic Engineering & $5.9 \%$ \\
\hline & Energy Engineering & $5.9 \%$ \\
\hline & Naval Architecture and Ocean & $2.9 \%$ \\
\hline & Engineering & 2.970 \\
\hline & Petroleum Engineering & $2.9 \%$ \\
\hline & Others & $8.8 \%$ \\
\hline \multirow{2}{*}{ Education level } & $\mathrm{MSc}$ & $67.6 \%$ \\
\hline & $\mathrm{PhD}$ & $32.4 \%$ \\
\hline \multirow{2}{*}{ Type of project } & Technology & $67.6 \%$ \\
\hline & Idea & $32.4 \%$ \\
\hline \multirow{2}{*}{ Inventor and non-inventor } & Inventor & $14.7 \%$ \\
\hline & Non-inventor & $85.3 \%$ \\
\hline \multirow[t]{2}{*}{ Entrepreneurial background } & $\begin{array}{l}\text { At least one experience in } \\
\text { practical entrepreneurship } \\
\text { programs }\end{array}$ & $50.0 \%$ \\
\hline & $\begin{array}{l}\text { No experience in practical } \\
\text { entrepreneurship programs }\end{array}$ & $50.0 \%$ \\
\hline
\end{tabular}

\section{Consistency of the Variables and Analyses}

\subsection{Consistency of the Variables}

The analyses carried out in the paper can be divided into two phases. The first phase is devoted to assessing the validity and reliability of the scales used to measure the students traits. The second phase regards the qualitative analysis of the impact of the program on the students' entrepreneurial traits. 
Regarding the first phase, the validity and internal consistency of the scales were assessed using a confirmatory factor analysis and Cronbach's alpha, respectively. Tables 3 and 4 show the results of the confirmatory factor analysis and Cronbach's alpha for both the pre-program and post-program data. The factor loadings for the pre-program data are greater than 0.50 , except for one item- $\mathrm{p} 4-$ of the "planning" scale. These results suggest a good level of validity for the scales (Fullerton and McWatters 2001). Moreover, the analysis performed on the pre-course data shows a greater Cronbach's alpha than 0.81 for eight of the ten variables, while the remaining two variables have values equal to 0.72 and 0.63 . Thus, good internal consistency of the variables built on the pre-program data is confirmed by Cronbach's alpha (Nunnally 1978). The results of the confirmatory analysis and Cronbach's alpha on post-program data are listed in Table 4. The factor loadings referring to the post-program data are greater than 0.50, thus showing a good level of validity. In this case, item $\mathrm{p} 4$ has a factor loading of 0.57 . Given the good factor loading of the post-program data and the inclusion of the aforementioned item in the scale validated in previous literature, we decided to include the item in the final scale. We also carried out the analysis without including item $\mathrm{p} 4$ in the scale to check the robustness of the results, and we obtained similar results.

Table 3. The factor loadings and Cronbach's alpha values obtained from the factor analysis conducted on the pre-program data.

\begin{tabular}{|c|c|c|c|}
\hline Variable & Item & Loading & Cronbach \\
\hline $\begin{array}{l}\text { Entrepreneurial } \\
\text { Intention }\end{array}$ & $\begin{array}{l}\text { ei_1 } \\
\text { ei_2 } \\
\text { ei_3 } \\
\text { ei_4 } \\
\text { ei_5 } \\
\text { ei_6 }\end{array}$ & $\begin{array}{l}0.5953 \\
0.9208 \\
0.7256 \\
0.9029 \\
0.7065 \\
0.8628\end{array}$ & 0.9034 \\
\hline $\begin{array}{c}\text { Entrepreneurial } \\
\text { Attitude }\end{array}$ & $\begin{array}{l}\text { ea_1 } \\
\text { ea_2 } \\
\text { ea_3 } \\
\text { ea_4 } \\
\text { ea_5 }\end{array}$ & $\begin{array}{l}0.5725 \\
0.8850 \\
0.8193 \\
0.8587 \\
0.8324\end{array}$ & 0.8883 \\
\hline $\begin{array}{c}\text { Entrepreneurial } \\
\text { Self-Efficacy }\end{array}$ & $\begin{array}{l}\text { ese_1 } \\
\text { ese_2 } \\
\text { ese_3 } \\
\text { ese_4 } \\
\text { ese_5 } \\
\text { ese_6 } \\
\text { ese_7 }\end{array}$ & $\begin{array}{l}0.8038 \\
0.7405 \\
0.9121 \\
0.7455 \\
0.7871 \\
0.6462 \\
0.8415\end{array}$ & 0.9128 \\
\hline $\begin{array}{c}\text { Entrepreneurial } \\
\text { Mindset }\end{array}$ & $\begin{array}{l}\text { em_1 } \\
\text { em_2 } \\
\text { em_3 }\end{array}$ & $\begin{array}{l}0.5109 \\
0.5330 \\
0.6326\end{array}$ & 0.6308 \\
\hline Core Self-Evaluation & $\begin{array}{l}\text { cse_1 } \\
\text { cse_2 } \\
\text { cse_3 } \\
\text { cse_4 } \\
\text { cse_5 }\end{array}$ & $\begin{array}{l}0.8688 \\
0.7135 \\
0.7128 \\
0.6826 \\
0.6453\end{array}$ & 0.8434 \\
\hline Creativity & $\begin{array}{l}\text { c_1 } \\
\text { c_2 } \\
\text { c_3 } \\
\text { c_4 }\end{array}$ & $\begin{array}{l}0.7498 \\
0.8972 \\
0.8414 \\
0.7905\end{array}$ & 0.8954 \\
\hline Financial Literacy & $\begin{array}{l}\mathrm{fl} \_1 \\
\mathrm{fl} \_2 \\
\mathrm{fl} 3\end{array}$ & $\begin{array}{l}0.7932 \\
0.9339 \\
0.9748\end{array}$ & 0.9289 \\
\hline
\end{tabular}


Table 3. Cont.

\begin{tabular}{cccc}
\hline Variable & Item & Loading & Cronbach \\
\hline \multirow{3}{*}{ Marshaling of } & mr_1 & 0.6192 & \\
Resources & mr_2 & 0.7342 & 0.8319 \\
& mr_3 & 0.8282 & \\
Planning & mr_4 & 0.7714 & \\
& p_1 & 0.8762 & 0.8197 \\
& p_2 & 0.9302 & \\
Teamwork & p_3 & 0.8283 & \multirow{2}{*}{0.7201} \\
& p_4 & 0.2025 & \\
\hline
\end{tabular}

Table 4. Factor loadings and Cronbach's alpha values obtained from the factor analysis conducted on the post-program data.

\begin{tabular}{|c|c|c|c|}
\hline Variable & Item & Loading & Cronbach \\
\hline \multirow{6}{*}{$\begin{array}{l}\text { Entrepreneurial } \\
\text { Intention }\end{array}$} & ei_1 & 0.7693 & \multirow{6}{*}{0.9343} \\
\hline & ei_2 & 0.8957 & \\
\hline & ei_3 & 0.8280 & \\
\hline & ei_4 & 0.9216 & \\
\hline & ei_5 & 0.8012 & \\
\hline & ei_6 & 0.8523 & \\
\hline \multirow{5}{*}{$\begin{array}{c}\text { Entrepreneurial } \\
\text { Attitude }\end{array}$} & ea_1 & 0.5771 & \multirow{5}{*}{0.9139} \\
\hline & ea_2 & 0.8693 & \\
\hline & ea_3 & 0.8517 & \\
\hline & ea_4 & 0.9521 & \\
\hline & ea_5 & 0.9083 & \\
\hline \multirow{7}{*}{$\begin{array}{c}\text { Entrepreneurial } \\
\text { Self-Efficacy }\end{array}$} & ese_1 & 0.5975 & \multirow{7}{*}{0.9029} \\
\hline & ese_2 & 0.7371 & \\
\hline & ese_3 & 0.9367 & \\
\hline & ese_4 & 0.6808 & \\
\hline & ese_5 & 0.6743 & \\
\hline & ese_6 & 0.8563 & \\
\hline & ese_7 & 0.8486 & \\
\hline \multirow{3}{*}{$\begin{array}{l}\text { Entrepreneurial } \\
\text { Mindset }\end{array}$} & em_1 & 0.5429 & \multirow{3}{*}{0.7249} \\
\hline & em_2 & 0.7446 & \\
\hline & em_3 & 0.7009 & \\
\hline \multirow{5}{*}{ Core Self-Evaluation } & cse_1 & 0.9093 & \multirow{5}{*}{0.8860} \\
\hline & cse_2 & 0.8174 & \\
\hline & cse_3 & 0.6947 & \\
\hline & cse_4 4 & 0.7220 & \\
\hline & cse_5 & 0.7849 & \\
\hline \multirow{4}{*}{ Creativity } & c_1 & 0.8497 & \multirow{4}{*}{0.9061} \\
\hline & c_2 & 0.8504 & \\
\hline & c_3 & 0.7900 & \\
\hline & c_4 4 & 0.8822 & \\
\hline \multirow{3}{*}{ Financial Literacy } & fl_1 & 0.7564 & \multirow{3}{*}{0.8935} \\
\hline & $\mathrm{fl} \_2$ & 0.8671 & \\
\hline & fl_3 & 0.9108 & \\
\hline
\end{tabular}


Table 4. Cont.

\begin{tabular}{|c|c|c|c|}
\hline Variable & Item & Loading & Cronbach \\
\hline $\begin{array}{l}\text { Marshaling of } \\
\text { Resources }\end{array}$ & $\begin{array}{l}\text { mr_1 } \\
\text { mr_2 } \\
\text { mr_3 } \\
\text { mr_4 }\end{array}$ & $\begin{array}{l}0.6889 \\
0.8472 \\
0.8605 \\
0.7757\end{array}$ & 0.8665 \\
\hline Planning & $\begin{array}{l}\text { P_1 } \\
\text { p_2 } \\
\text { p_3 } \\
\text { p_4 }\end{array}$ & $\begin{array}{l}0.8139 \\
0.8507 \\
0.8849 \\
0.5700\end{array}$ & 0.8529 \\
\hline Teamwork & $\begin{array}{l}\mathrm{tw}+1 \\
\mathrm{tw} \text { _2 } \\
\mathrm{tw} \text { _3 }\end{array}$ & $\begin{array}{l}0.6702 \\
0.7812 \\
0.8883\end{array}$ & 0.8346 \\
\hline
\end{tabular}

\subsection{Qualitative Analyses}

This section presents the results of the second phase, the qualitative analysis. During this phase, we investigated the impact of participation in the program on the ten variables. Specifically, we measured the impact of the program on the variables in relation to four categories: gender, level of education (MSc or PhD), entrepreneurial background and type of project (technology or idea).

On a practical level, we compared, for each of the ten variables, the average value before and after CAST to assess the impact of the program on the individual entrepreneurial characteristics of the whole sample. We then performed the same comparison by breaking down the sample in relation to the four categories to assess the presence of any possible intra-category difference. The mean value of each variable was calculated as the average of the values of each student's variable, e.g., the mean value of the entrepreneurial intention of the whole sample was obtained as the average of the values of each student's entrepreneurial intention. In turn, the variable value for each student was calculated as the mean of the items of its scale.

We first present the results obtained without using any classification of the sample. We then present the results obtained by categorizing the sample in relation to gender, level of education (MSc or PhD), entrepreneurial background and type of project (technology or idea).

Figure 1 shows the pre-course and post-course values of the entire sample concerning the ten entrepreneurial dimensions of the students. All the variables show an increase from the beginning to the end of the program. A marked increase (0.98) emerges in the case of financial literacy, which shows a particularly low value for before the start of the program, compared to the other variables. This increase is probably due to the particular nature of this knowledge, which engineering students often do not possess. Marshaling of resources (0.64) and entrepreneurial self-efficacy (0.67) also show a large increase. This latter result shows greater confidence of the students in their entrepreneurial traits after participating in the program. These results might be related to a greater awareness of their capabilities, obtained thanks to the practical approach that encourages the students to face all the activities concerning the development of an entrepreneurial project. Finally, the only characteristic that shows an almost zero increase between the pre- and post-course results is teamwork. This could be due to the transversality of this aspect, which the students who decide to participate in programs of this type generally have, regardless of their academic background. Furthermore, this could derive from the online setting of the course, which could have made interaction within teams difficult and consequently hindered any improvement in teamwork skills. 


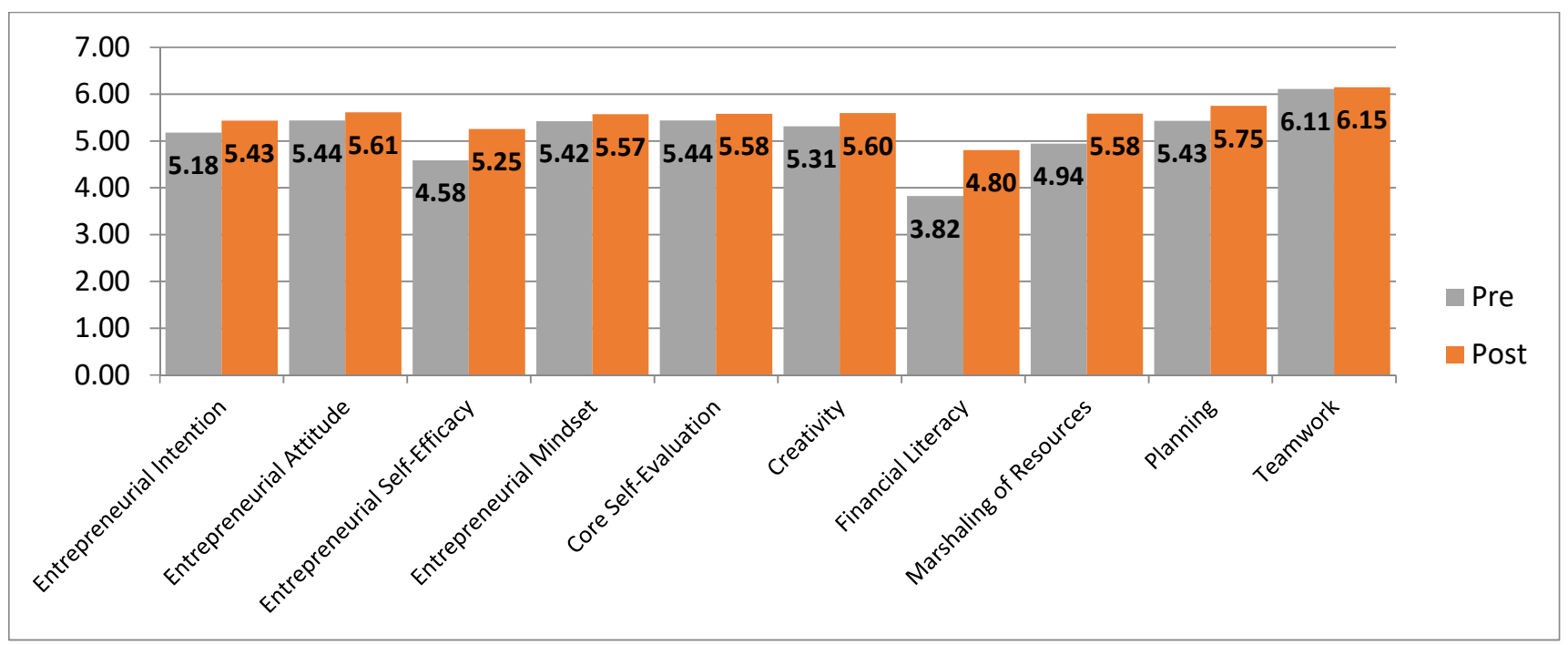

Figure 1. The average values of entrepreneurial characteristics, pre- and post-course.

The values of the pre- and post-course entrepreneurial traits, in relation to the gender of the students, can be observed in Figure 2 (Female) and Figure 3 (Male). Both categories present an increase from the pre- to the post-course values for all the analyzed dimensions. More interestingly, both categories show a similar increase for all the variables, except for the entrepreneurial intention and planning variables. This result suggests that the program with a practice-oriented approach is equally effective in improving the entrepreneurial traits of both categories and is not affected by gender biases.

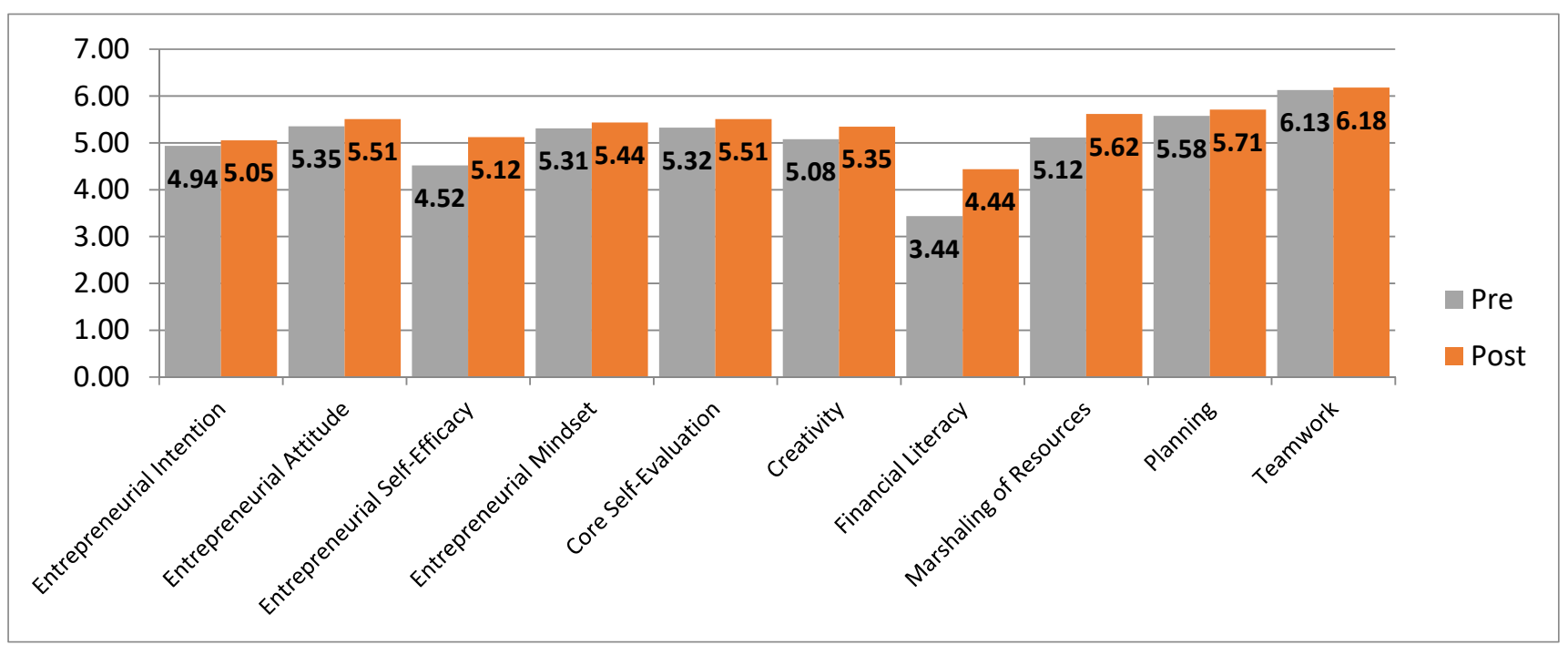

Figure 2. The average values of the entrepreneurial characteristics, pre- and post-course, of the female students. 


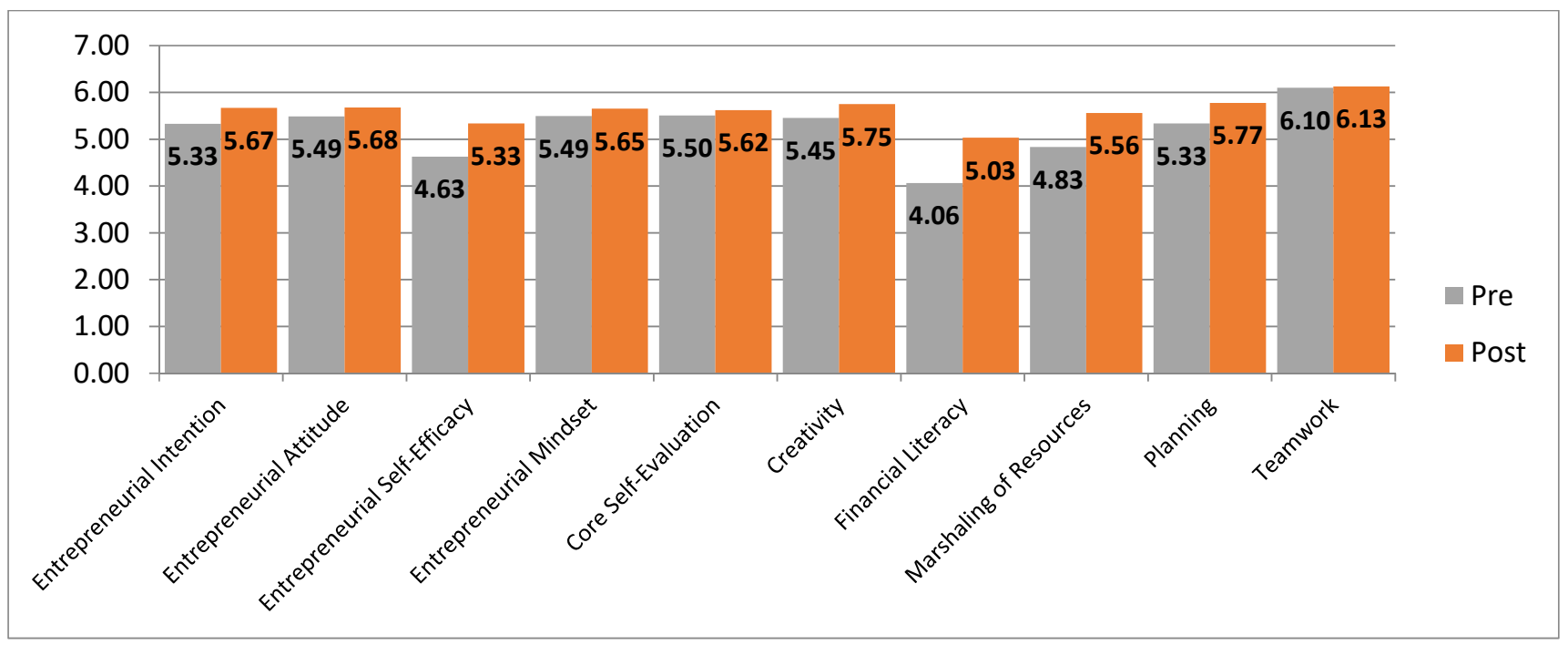

Figure 3. The average values of the entrepreneurial characteristics, pre- and post-course, of the male students.

Figures 4 and 5 refer to the pre- and post-values of the students attending a Master of Science degree program or a PhD program, respectively. Both the MSc and PhD students show an increase in all the variables, except for teamwork for the PhD students. Despite the growth in the variables, it seems that the program had different effects on the MSc students than the PhD students. The MSc students show a higher growth of entrepreneurial attitude and entrepreneurial intention than the $\mathrm{PhD}$ students. These results could reflect a higher commitment of the PhD students to an academic career than MSc students, who have not yet entered the job market or an academic path. On the other hand, the $\mathrm{PhD}$ students show greater growth than the MSc students in entrepreneurial self-efficacy, marshaling of resources, and planning. PhD students usually operate in high uncertainty and time-constrained environments (Gould 2015). In such an environment, entrepreneurial concepts could be easier to assimilate, appreciate and exploit, thereby resulting in a higher performance of the PhD students (Colombelli et al. 2021b).

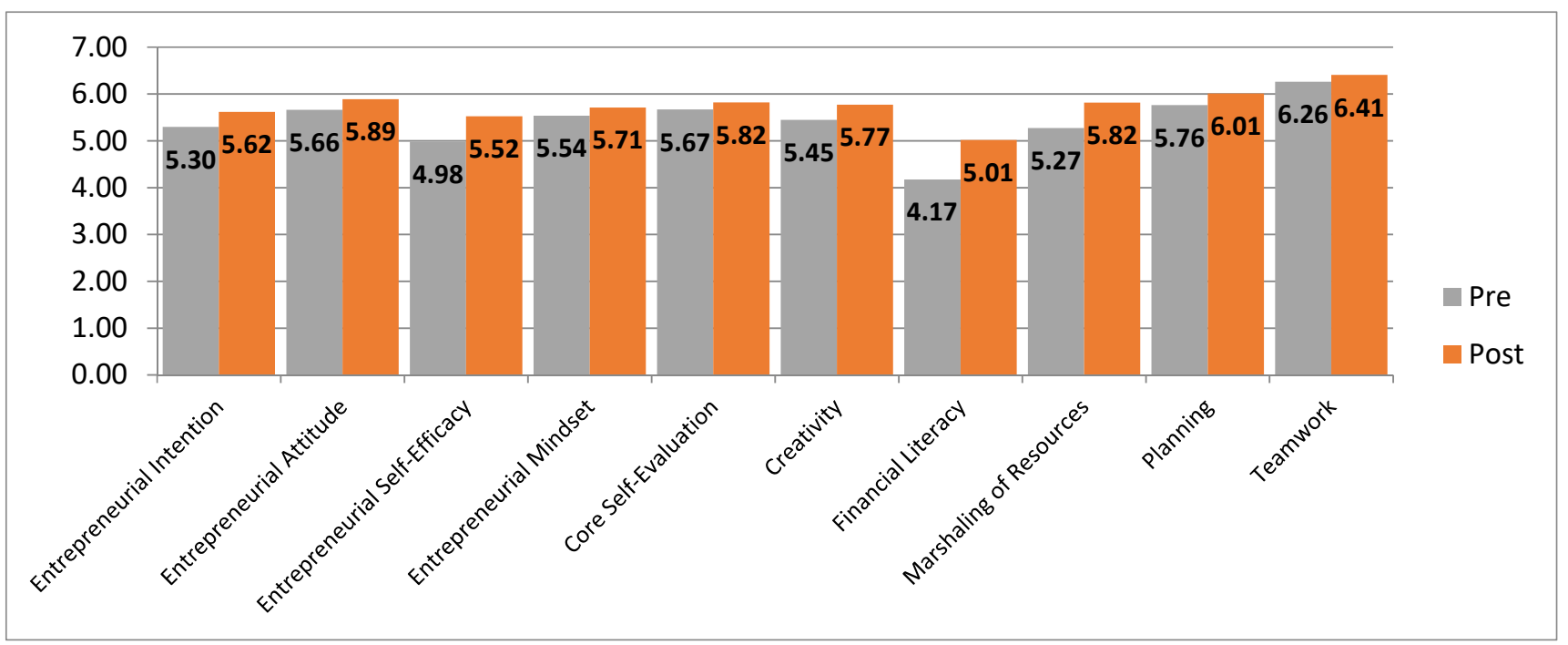

Figure 4. The average values of the entrepreneurial characteristics, pre- and post-course, of the MSc students. 


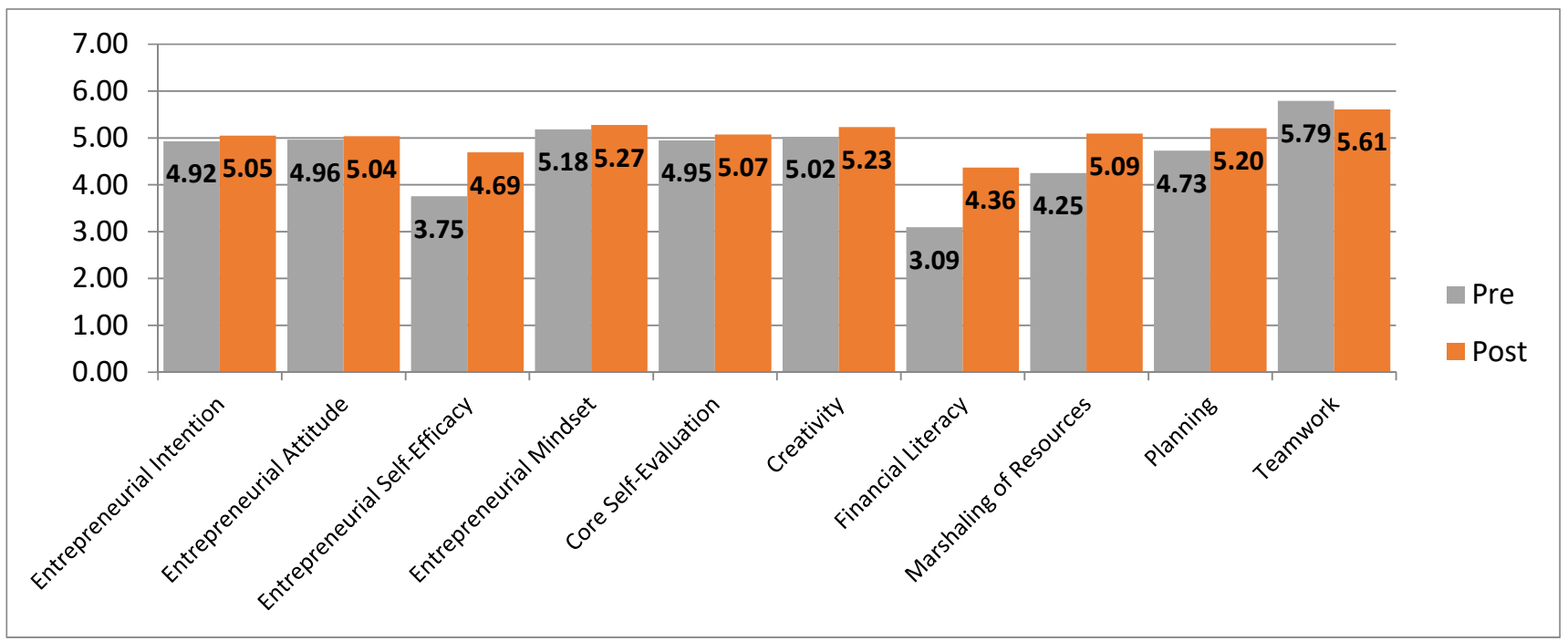

Figure 5. The average values of the entrepreneurial characteristics, pre- and post-course, of the $\mathrm{PhD}$ students.

The next analyzed category is the entrepreneurial background of the students. The students were divided into two groups: (1) students who had already taken part in practiceoriented entrepreneurship programs (Figure 6); (2) students without any experience of practice-oriented entrepreneurship programs (Figure 7). As we can see from Figures 6 and 7 , there are differences between the two categories. In general, there is an increase from the pre to the post values, except for teamwork $(-0.20)$ and entrepreneurial mindset $(-0.02)$ for those who participated in such a program for the first time. Looking at Figures 6 and 7 , it seems that the program was more effective for those who had already participated in other entrepreneurial programs, with respect to the entrepreneurial mindset and teamwork variables. As far as entrepreneurial self-efficacy, financial literacy and marshaling of resources are concerned, there is a clear increase in favor of those who had never participated in entrepreneurial programs. Such a marked increase might suggest that these kinds of entrepreneurial programs may be more effective for those students with fewer entrepreneurial skills and abilities.

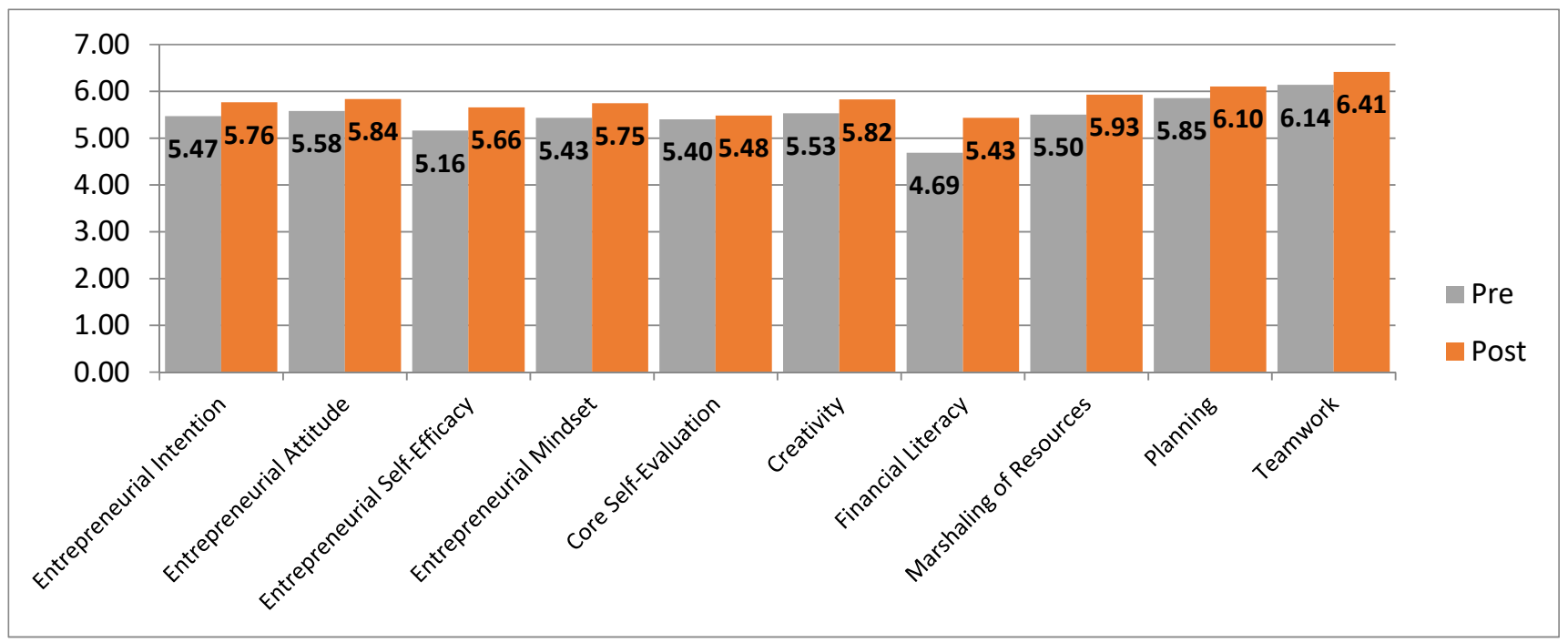

Figure 6. The average values of the entrepreneurial characteristics, pre- and post-course, of the students who had had at least one experience in practical entrepreneurship programs. 


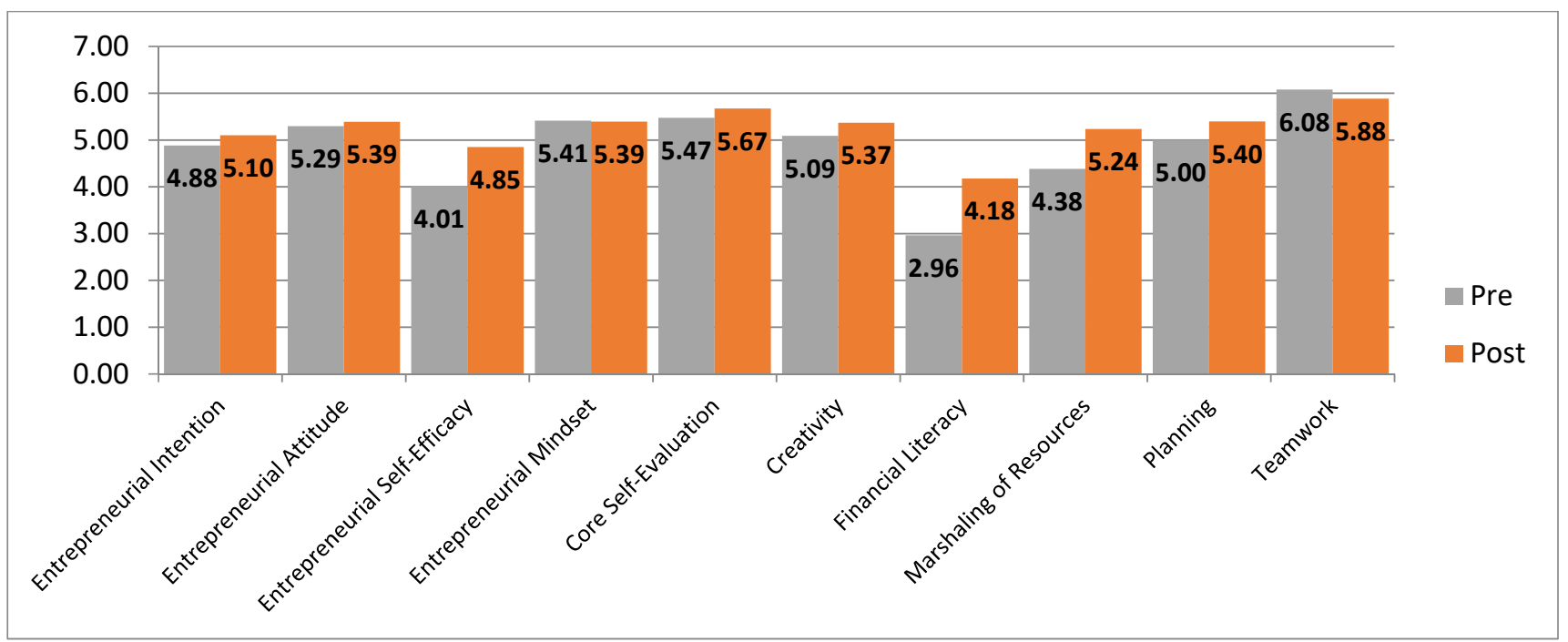

Figure 7. The average values of the entrepreneurial characteristics, pre- and post-course, of the students who had had no experience in practical entrepreneurship programs.

Finally, we also investigated the differential impact that the program had on students who worked on patented technologies developed in an academic context (Figure 8) compared to students who worked on entrepreneurial ideas proposed by other students (Figure 9). Figures 8 and 9 show that all the characteristics grew from the pre- to the post-course, except for teamwork $(-0.01)$ for those who worked on patented technologies. Moreover, they also reveal that the increase for most variables is similar for those who worked on a technology and those who worked on an idea. The few exceptions are entrepreneurial attitude and creativity, which increase more for the students who worked on a technology, and core self-evaluation, which increases more for the students who worked on an idea. In general, these results suggest that the program had a similar effect on the students, regardless of the project they were assigned to.

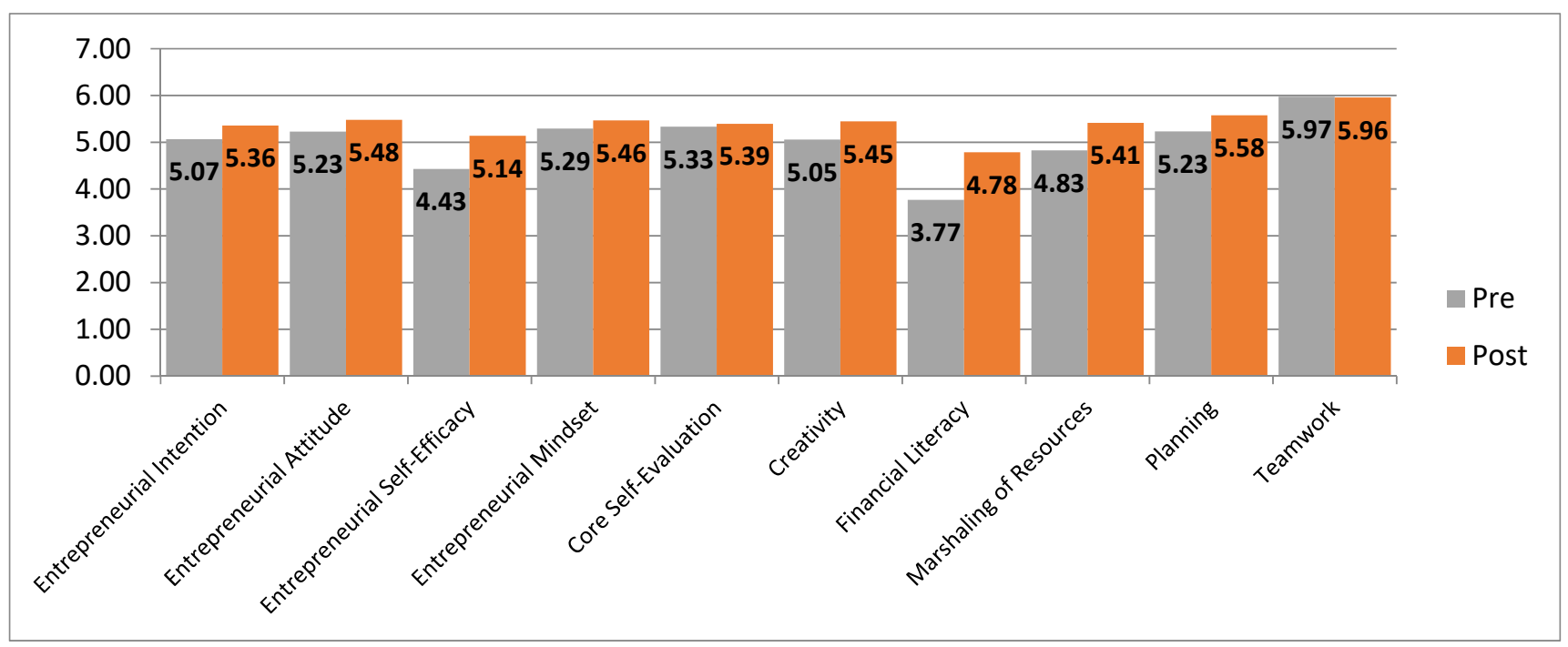

Figure 8. The average values of the entrepreneurial characteristics, pre- and post-course, of the students who worked on patented technologies. 


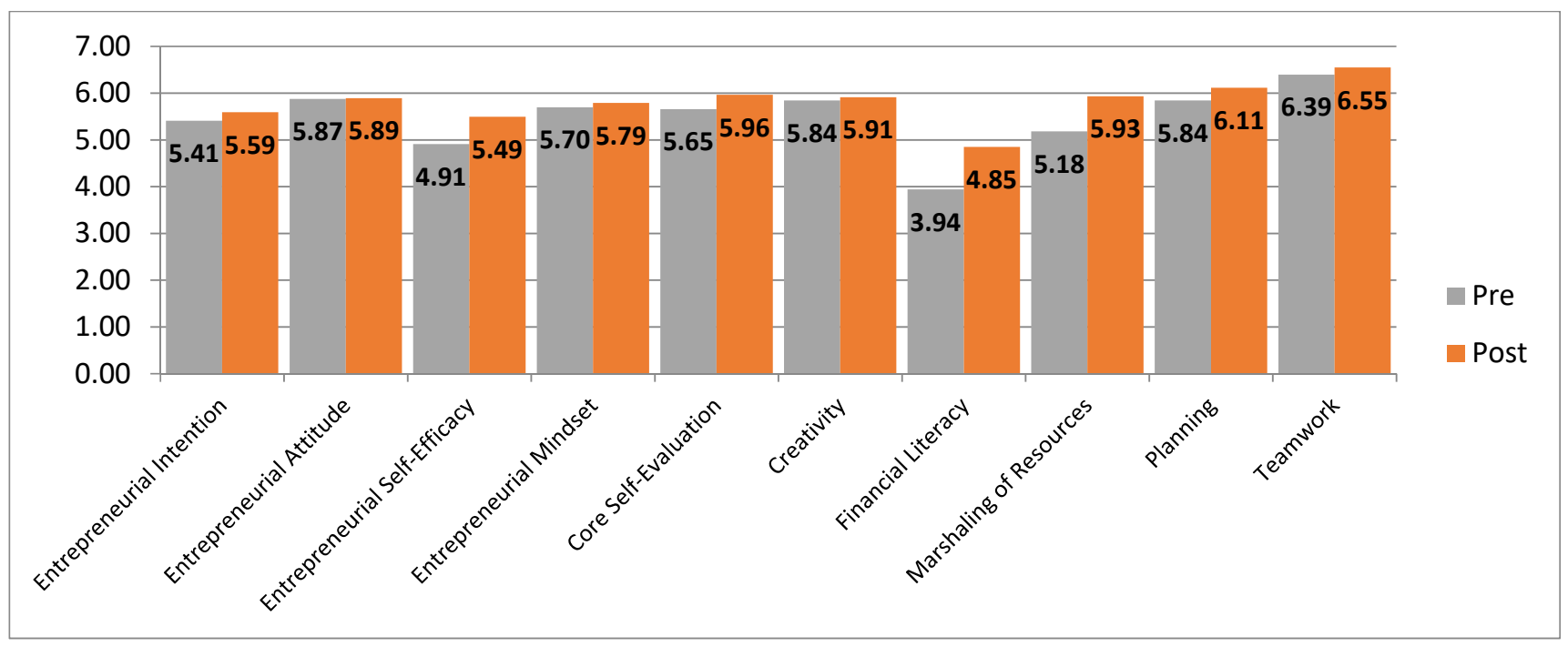

Figure 9. The average values of the entrepreneurial characteristics, pre- and post-course, of the students who worked on entrepreneurial ideas proposed by other students.

In short, the results show that the program had a positive impact on the participants, as it improved their entrepreneurial traits. On the one hand, the results show that the program generated a similar impact, regardless of the gender of the students and the project to which they had been assigned (technology vs. idea). On the other hand, the program seems to be more effective for students with no previous experience in entrepreneurship courses that adopt a practice-oriented approach. Finally, a difference in effectiveness also seems to emerge between MSc and PhD students.

\section{Conclusions}

This study, by taking part in the recent debate on entrepreneurship education, aims to provide evidence on the effectiveness of short-intensive entrepreneurship programs that adopt a practice-oriented approach to the entrepreneurial traits of students. In this vein, we have analyzed a short intensive online entrepreneurial program that adopts a learning-by-doing approach, which is offered to MSc and $\mathrm{PhD}$ students from four European technical universities. Furthermore, the program has also allowed us to study the impact on entrepreneurial traits and to pay attention to various dimensions, such as the level of entrepreneurial background, educational level, gender and the type of entrepreneurial projects to which the students had been assigned. Moreover, both students with previous experience in entrepreneurship programs that adopt a practice-oriented approach and students who had no previous experience of such programs were involved in the program. Finally, the students had the opportunity to choose and work on either a technology from the Politecnico di Torino or an entrepreneurial idea proposed by other students.

We collected pre- and post-course data on the students' entrepreneurial intention, entrepreneurial characteristics (entrepreneurial attitude, entrepreneurial self-efficacy, entrepreneurial mindset, core self-evaluation) and entrepreneurial skills (creativity, financial literacy, marshaling of resources, planning, teamwork), to assess the effect of the program.

The results of the analyses on the pre- and post-course data show a positive impact of the program on the entrepreneurial traits of the students for the whole sample. The results, in particular, show an improvement from the pre- to the post-CAST on all the dimensions, except for teamwork, which remained almost unchanged. The lack of variation for teamwork is probably due to the online setting of the course which may have limited the dynamics within the teams. The analyses we carried out show that the program does not result in any substantial differences, in terms of effectiveness, in relation to gender or in relation to the type of project on which the students worked (patented technology or idea proposed by other students). Instead, differences emerge between the MSc and 
PhD students. Indeed, the program appears to increase the entrepreneurial intention and entrepreneurial attitude of MSc students more than those of PhD students. Conversely, there is a higher positive impact of the program on the entrepreneurial self-efficacy of PhD students than that of MSc students. Furthermore, the program seems to be more effective for those students who are participating for the first time in a practice-oriented entrepreneurship course than for those students who have had previous experience in such a course.

This study is not without limitations. First, the study was focused on a single case study, from which few observations are available, thus the sample size does not allow the results to be generalized. Moreover, the program involved students mainly from the Politecnico di Torino, although it was an international program. Consequently, it was not possible to carry out analyses on the impact of the program on students' entrepreneurial traits in relation to their affiliation. Furthermore, no control sample was available.

Future research could be directed toward investigating the impact of similar programs using a larger dataset. Furthermore, by using a larger dataset, future works could investigate other possible dimensions that could affect the impact of such programs, such as the students' field of study and/or their nationality. In addition, it might be useful to collect further data about students' family entrepreneurial background, so as to investigate a possible impact of the program in relation to, for example, the presence of entrepreneurial parents.

In conclusion, the study has shed light on how practice-oriented entrepreneurship courses can affect the entrepreneurial traits of its participants. Furthermore, it shows how entrepreneurship courses may have a differential impact on the participants, taking into account their gender, educational level, prior entrepreneurial experience and the project on which they have worked. The findings of the study have important implications for universities in terms of the designing of entrepreneurship programs. In particular, they show that short, intensive entrepreneurship programs that adopt a learning-by-doing approach are effective. Such programs, as the study shows, help to create awareness in students who have never participated in entrepreneurship courses of this kind. Moreover, the involvement of students with different levels of education in these programs seems to be effective. A further implication concerns the involvement of inventors who conceived and developed technologies on which the teams work in the student teams. Inventors, who often have years of research experience, do not always understand the commercialization potential of their technologies and, from this point of view, students can offer support. However, given their commitment to their academic careers, it is difficult to involve such inventors in long-term programs, and for this reason, it is important for universities to know that even short-term programs are effective in relation to the presence of inventors. Finally, demonstrating how the interaction between students and inventors contributes to the discovery of commercialization potential is also an important implication for university technology transfer offices that have the aim of economically exploiting the results of scientific research.

Author Contributions: Writing-original draft preparation, A.C., A.P. and F.S.; writing-review and editing, A.C., A.P. and F.S. All authors have read and agreed to the published version of the manuscript.

Funding: This research received no external funding.

Informed Consent Statement: Informed consent was obtained from all subjects involved in the study.

Data Availability Statement: Not applicable.

Conflicts of Interest: The authors declare no conflict of interest. 


\section{Appendix A}

$T$-tests were carried out to analyze the difference between the post- and pre-course values on the whole sample and by breaking down the sample according to gender, educational level, entrepreneurial background and type of entrepreneurial project. In particular, for each of the four categories, two $t$-tests were conducted, one for each of the possible values of the categories. The results of the tests are reported below:

- Table A1 shows the output of the $t$-test in relation to the whole sample;

- Table A2 shows the output of the $t$-test in relation to the male students;

- Table A3 shows the output of the $t$-test in relation to the female students;

- Table A4 shows the output of the $t$-test in relation to the MSc students;

- Table A5 shows the output of the $t$-test in relation to the PhD students;

- Table A6 shows the output of the $t$-test in relation to the students who had had at least one experience in practical entrepreneurship programs;

- Table A7 shows the output of the $t$-test in relation to the students who had had no experience in practical entrepreneurship programs;

- Table A8 shows the output of the $t$-test in relation to the students who worked on patented technologies;

- Table A9 shows the output of the $t$-test in relation to the students who worked on entrepreneurial ideas proposed by other students.

In each table, it is possible to observe for each variable the pre-course value, the post-course value, the difference between the post- and pre-course value, and the $p$-value related to the alternative hypothesis (Ha: difference between post- and pre-course greater than zero).

Table A1. Output of $t$-tests on entrepreneurial characteristics, pre- and post-course, of the whole sample.

\begin{tabular}{|c|c|c|c|c|}
\hline Variable & $\begin{array}{c}\text { Average Pre } \\
\text { CAST }\end{array}$ & $\begin{array}{l}\text { Average Post } \\
\text { CAST }\end{array}$ & $\begin{array}{c}\text { diff }=\text { avg post } \\
\text { CAST }- \\
\text { avg pre CAST } \\
(\text { Ho: diff }=0)\end{array}$ & $\begin{array}{c}p \text {-Value } \\
\text { (Ha: } \text { diff }>0 \text { ) }\end{array}$ \\
\hline $\begin{array}{l}\text { Entrepreneurial } \\
\text { Intention }\end{array}$ & 5.176471 & 5.431373 & 0.254902 & 0.1885 \\
\hline $\begin{array}{c}\text { Entrepreneurial } \\
\text { Attitude }\end{array}$ & 5.435294 & 5.029412 & -0.4058824 & 0.9545 \\
\hline $\begin{array}{l}\text { Entrepreneurial } \\
\text { Self-Efficacy }\end{array}$ & 4.584034 & 5.264706 & 0.6806723 & $0.0068^{* * *}$ \\
\hline $\begin{array}{c}\text { Entrepreneurial } \\
\text { Mindset }\end{array}$ & 5.421569 & 5.588235 & 0.1666667 & 0.2319 \\
\hline $\begin{array}{c}\text { Core Self } \\
\text { Evaluation }\end{array}$ & 5.435294 & 5.647059 & 0.2117647 & 0.1924 \\
\hline Creativity & 5.308824 & 4.764706 & -0.5441176 & 0.9644 \\
\hline $\begin{array}{l}\text { Financial } \\
\text { Literacy }\end{array}$ & 3.823529 & 5.470588 & 1.647059 & $0.0000^{* * *}$ \\
\hline $\begin{array}{l}\text { Marshalling of } \\
\text { Resources }\end{array}$ & 4.941176 & 5.411765 & 0.4705882 & $0.0494^{* *}$ \\
\hline Planning & 5.426471 & 6.294118 & 0.8676471 & $0.0001^{* * *}$ \\
\hline Teamwork & 6.107843 & 6.098039 & -0.0098039 & 0.5223 \\
\hline
\end{tabular}


Table A2. Output of $t$-tests on entrepreneurial characteristics, pre- and post-course, of the male students.

\begin{tabular}{ccccc}
\hline Variable & $\begin{array}{c}\text { Average Pre } \\
\text { CAST }\end{array}$ & $\begin{array}{c}\text { Average Post } \\
\text { CAST }\end{array}$ & $\begin{array}{c}\text { diff }=\text { avg post } \\
\text { CAST }- \\
\text { avg pre CAST } \\
\text { (Ho: diff }=\mathbf{0})\end{array}$ & $\begin{array}{c}p \text {-Value } \\
\text { (Ha: diff }>\text { 0) }\end{array}$ \\
\hline $\begin{array}{c}\text { Entrepreneurial } \\
\text { Intention }\end{array}$ & 5.325397 & 5.666667 & 0.3412698 & 0.1602 \\
\hline $\begin{array}{c}\text { Entrepreneurial } \\
\text { Attitude }\end{array}$ & 5.485714 & 5.047619 & -0.4380952 & 0.9470 \\
\hline $\begin{array}{c}\text { Entrepreneurial } \\
\text { Self-Efficacy }\end{array}$ & 4.62585 & 5.380952 & 0.755102 & $0.0210^{* *}$ \\
\hline $\begin{array}{c}\text { Entrepreneurial } \\
\text { Mindset }\end{array}$ & 5.492063 & 5.714286 & 0.2222222 & 0.1710 \\
\hline $\begin{array}{c}\text { Core Self } \\
\text { Evaluation }\end{array}$ & 5.504762 & 5.904762 & 0.4 & $0.0676^{*}$ \\
\hline Creativity & 5.452381 & 4.952381 & -0.5 & 0.9322 \\
\hline $\begin{array}{c}\text { Financial } \\
\text { Literacy }\end{array}$ & 4.063492 & 5.47619 & 1.412698 & $0.0001^{* * *}$ \\
\hline $\begin{array}{c}\text { Marshalling of } \\
\text { Resources }\end{array}$ & 4.833333 & 5.47619 & 0.6428571 & $0.0407 * *$ \\
\hline $\begin{array}{c}\text { Planning } \\
\text { Teamwork }\end{array}$ & 5.333333 & 6.285714 & 0.952381 & $0.0001^{* * *}$ \\
\hline *** $p<0.01{ }^{* *} p<0.05{ }^{* *} p<0.1$. & 6.074074 & -0.021164 & 0.5401 \\
\hline
\end{tabular}

Table A3. Output of $t$-tests on entrepreneurial characteristics, pre- and post-course, of the female students.

\begin{tabular}{ccccc}
\hline Variable & $\begin{array}{c}\text { Average Pre } \\
\text { CAST }\end{array}$ & $\begin{array}{c}\text { Average Post } \\
\text { CAST }\end{array}$ & $\begin{array}{c}\text { diff }=\text { avg post } \\
\text { CAST }- \\
\text { avg pre CAST } \\
\text { (Ho: diff }=\mathbf{0})\end{array}$ & $\begin{array}{c}p \text {-Value } \\
\text { (Ha: diff }>\text { 0) }\end{array}$ \\
\hline $\begin{array}{c}\text { Entrepreneurial } \\
\text { Intention }\end{array}$ & 4.935897 & 5.051282 & 0.1153846 & 0.4104 \\
\hline $\begin{array}{c}\text { Entrepreneurial } \\
\text { Attitude }\end{array}$ & 5.353846 & 5 & -0.3538462 & 0.7747 \\
\hline $\begin{array}{c}\text { Entrepreneurial } \\
\text { Self-Efficacy }\end{array}$ & 4.516484 & 5.076923 & 0.5604396 & $0.0906^{*}$ \\
\hline $\begin{array}{c}\text { Entrepreneurial } \\
\text { Mindset }\end{array}$ & 5.307692 & 5.384615 & 0.0769231 & 0.4351 \\
\hline $\begin{array}{c}\text { Core Self } \\
\text { Evaluation }\end{array}$ & 5.323077 & 5.230769 & -0.0923077 & 0.5788 \\
\hline Creativity & 5.076923 & 4.461538 & -0.6153846 & 0.8551 \\
\hline $\begin{array}{c}\text { Financial } \\
\text { Literacy }\end{array}$ & 3.435897 & 5.461538 & 2.025641 & $0.0004^{* * *}$ \\
\hline $\begin{array}{c}\text { Marshalling of } \\
\text { Resources }\end{array}$ & 5.115385 & 5.307692 & 0.1923077 & 0.3409 \\
\hline $\begin{array}{c}\text { Planning } \\
\text { Teamwork }\end{array}$ & 5.576923 & 6.307692 & 0.7307692 & $0.0514^{*}$ \\
\hline *** $p<0.01{ }^{* * *} p<0.05, *<0.1$. & 6.136752 & 0.008547 & 0.4894 \\
\hline
\end{tabular}


Table A4. Output of $t$-tests on entrepreneurial characteristics, pre- and post-course, of the MSc students.

\begin{tabular}{|c|c|c|c|c|}
\hline Variable & $\begin{array}{c}\text { Average Pre } \\
\text { CAST }\end{array}$ & $\begin{array}{c}\text { Average Post } \\
\text { CAST }\end{array}$ & $\begin{array}{c}\text { diff }=\text { avg post } \\
\text { CAST }- \\
\text { avg pre CAST } \\
(\text { Ho: } \text { diff }=0)\end{array}$ & $\begin{array}{c}p \text {-Value } \\
\text { (Ha: diff }>0 \text { ) }\end{array}$ \\
\hline $\begin{array}{l}\text { Entrepreneurial } \\
\text { Intention }\end{array}$ & 5.297101 & 5.615942 & 0.3188406 & 0.2004 \\
\hline $\begin{array}{c}\text { Entrepreneurial } \\
\text { Attitude }\end{array}$ & 5.66087 & 5.130435 & -0.5304348 & 0.9582 \\
\hline $\begin{array}{l}\text { Entrepreneurial } \\
\text { Self-Efficacy }\end{array}$ & 4.981366 & 5.391304 & 0.4099379 & 0.0808 * \\
\hline $\begin{array}{c}\text { Entrepreneurial } \\
\text { Mindset }\end{array}$ & 5.536232 & 5.913043 & 0.3768116 & 0.0880 * \\
\hline $\begin{array}{l}\text { Core Self } \\
\text { Evaluation }\end{array}$ & 5.669565 & 5.73913 & 0.0695652 & 0.4121 \\
\hline Creativity & 5.445652 & 4.869565 & -0.576087 & 0.9384 \\
\hline $\begin{array}{l}\text { Financial } \\
\text { Literacy }\end{array}$ & 4.173913 & 5.652174 & 1.478261 & $0.0000 * * *$ \\
\hline $\begin{array}{l}\text { Marshalling of } \\
\text { Resources }\end{array}$ & 5.271739 & 5.608696 & 0.3369565 & 0.1405 \\
\hline Planning & 5.76087 & 6.608696 & 0.8478261 & $0.0001^{* * *}$ \\
\hline Teamwork & 6.26087 & 6.338164 & 0.0772947 & 0.3337 \\
\hline
\end{tabular}

Table A5. Output of $t$-tests on the entrepreneurial characteristics, pre- and post-course, of the PhD students.

\begin{tabular}{|c|c|c|c|c|}
\hline Variable & $\begin{array}{c}\text { Average Pre } \\
\text { CAST }\end{array}$ & $\begin{array}{l}\text { Average Post } \\
\text { CAST }\end{array}$ & $\begin{array}{c}\text { diff }=\text { avg post } \\
\text { CAST }- \\
\text { avg pre CAST } \\
(\text { Ho: diff }=0)\end{array}$ & $\begin{array}{c}p \text {-Value } \\
\text { (Ha: diff }>0)\end{array}$ \\
\hline $\begin{array}{l}\text { Entrepreneurial } \\
\text { Intention }\end{array}$ & 4.924242 & 5.045455 & 0.1212121 & 0.3813 \\
\hline $\begin{array}{c}\text { Entrepreneurial } \\
\text { Attitude }\end{array}$ & 4.963636 & 4.818182 & -0.1454545 & 0.6613 \\
\hline $\begin{array}{c}\text { Entrepreneurial } \\
\text { Self-Efficacy }\end{array}$ & 3.753247 & 5 & 1.246753 & $0.0099 * * *$ \\
\hline $\begin{array}{l}\text { Entrepreneurial } \\
\text { Mindset }\end{array}$ & 5.181818 & 4.909091 & -0.2727273 & 0.8008 \\
\hline $\begin{array}{l}\text { Core Self } \\
\text { Evaluation }\end{array}$ & 4.945455 & 5.454545 & 0.5090909 & 0.0708 * \\
\hline Creativity & 5.022727 & 4.545455 & -0.4772727 & 0.8195 \\
\hline $\begin{array}{l}\text { Financial } \\
\text { Literacy }\end{array}$ & 3.090909 & 5.090909 & 2 & $0.0004^{* * *}$ \\
\hline $\begin{array}{l}\text { Marshalling of } \\
\text { Resources }\end{array}$ & 4.25 & 5 & 0.75 & 0.0828 * \\
\hline Planning & 4.727273 & 5.636364 & 0.9090909 & $0.0125^{* *}$ \\
\hline Teamwork & 5.787879 & 5.59596 & -0.1919192 & 0.7137 \\
\hline
\end{tabular}


Table A6. Output of $t$-tests on entrepreneurial characteristics, pre- and post-course, of the students who had had at least one experience in practical entrepreneurship programs.

\begin{tabular}{ccccc}
\hline Variable & $\begin{array}{c}\text { Average Pre } \\
\text { CAST }\end{array}$ & $\begin{array}{c}\text { Average Post } \\
\text { CAST }\end{array}$ & $\begin{array}{c}\text { diff }=\text { avg post } \\
\text { CAST }- \\
\text { avg pre CAST } \\
\text { (Ho: diff }=\mathbf{0})\end{array}$ & $\begin{array}{c}p \text {-Value } \\
\text { (Ha: diff }>\text { 0) }\end{array}$ \\
\hline $\begin{array}{c}\text { Entrepreneurial } \\
\text { Intention }\end{array}$ & 5.470588 & 5.764706 & 0.2941176 & 0.2196 \\
\hline $\begin{array}{c}\text { Entrepreneurial } \\
\text { Attitude }\end{array}$ & 5.576471 & 5.117647 & -0.4588235 & 0.9339 \\
\hline $\begin{array}{c}\text { Entrepreneurial } \\
\text { Self-Efficacy }\end{array}$ & 5.159664 & 5.352941 & 0.1932773 & 0.2594 \\
\hline $\begin{array}{c}\text { Entrepreneurial } \\
\text { Mindset }\end{array}$ & 5.431373 & 5.647059 & 0.2156863 & 0.2499 \\
\hline $\begin{array}{c}\text { Core Self } \\
\text { Evaluation }\end{array}$ & 5.4 & 5.882353 & 0.4823529 & $0.0847 *$ \\
\hline Creativity & 5.529412 & 5.294118 & -0.2352941 & 0.7409 \\
\hline $\begin{array}{c}\text { Financial } \\
\text { Literacy }\end{array}$ & 4.686275 & 5.588235 & 0.9019608 & $0.0112 * *$ \\
\hline $\begin{array}{c}\text { Marshalling of } \\
\text { Resources }\end{array}$ & 5.5 & 5.764706 & 0.2647059 & 0.1863 \\
\hline $\begin{array}{c}\text { Planning } \\
\text { Teamwork }\end{array}$ & 5.852941 & 6.647059 & 0.7941176 & $0.0004 * * *$ \\
\hline$* * * 137255$ & 6.333333 & 0.1960784 & 0.1846 \\
\hline$<0.01{ }^{* *} p<0.05{ }^{* *} p<0.1$. & & & \\
\hline
\end{tabular}

Table A7. Output of $t$-tests on entrepreneurial characteristics, pre- and post-course, of the students who had had no experience in practical entrepreneurship programs.

\begin{tabular}{|c|c|c|c|c|}
\hline Variable & $\begin{array}{c}\text { Average Pre } \\
\text { CAST }\end{array}$ & $\begin{array}{c}\text { Average Post } \\
\text { CAST }\end{array}$ & $\begin{array}{c}\text { diff }=\text { avg post } \\
\text { CAST }- \\
\text { avg pre CAST } \\
(\text { Ho: } \text { diff }=0)\end{array}$ & $\begin{array}{c}p \text {-Value } \\
\text { (Ha: diff }>0)\end{array}$ \\
\hline $\begin{array}{l}\text { Entrepreneurial } \\
\text { Intention }\end{array}$ & 4.882353 & 5.098039 & 0.2156863 & 0.3039 \\
\hline $\begin{array}{c}\text { Entrepreneurial } \\
\text { Attitude }\end{array}$ & 5.294118 & 4.941176 & -0.3529412 & 0.8242 \\
\hline $\begin{array}{c}\text { Entrepreneurial } \\
\text { Self-Efficacy }\end{array}$ & 4.008403 & 5.176471 & 1.168067 & $0.0037^{* * *}$ \\
\hline $\begin{array}{l}\text { Entrepreneurial } \\
\text { Mindset }\end{array}$ & 5.411765 & 5.529412 & 0.1176471 & 0.3630 \\
\hline $\begin{array}{l}\text { Core Self } \\
\text { Evaluation }\end{array}$ & 5.470588 & 5.411765 & -0.0588235 & 0.5678 \\
\hline Creativity & 5.088235 & 4.235294 & -0.8529412 & 0.9697 \\
\hline $\begin{array}{l}\text { Financial } \\
\text { Literacy }\end{array}$ & 2.960784 & 5.352941 & 2.392157 & $0.0000 * * *$ \\
\hline $\begin{array}{l}\text { Marshalling of } \\
\text { Resources }\end{array}$ & 4.382353 & 5.058824 & 0.6764706 & 0.0631 * \\
\hline Planning & 5 & 5.941176 & 0.9411765 & $0.0030 * * *$ \\
\hline Teamwork & 6.078431 & 5.862745 & -0.2156863 & 0.7855 \\
\hline
\end{tabular}


Table A8. Output of $t$-tests on entrepreneurial characteristics, pre- and post-course, of the students who worked on patented technologies.

\begin{tabular}{ccccc}
\hline Variable & $\begin{array}{c}\text { Average Pre } \\
\text { CAST }\end{array}$ & $\begin{array}{c}\text { Average Post } \\
\text { CAST }\end{array}$ & $\begin{array}{c}\text { diff }=\text { avg post } \\
\text { CAST }- \\
\text { avg pre CAST } \\
\text { (Ho: diff }=\mathbf{0})\end{array}$ & $\begin{array}{c}p \text {-Value } \\
\text { (Ha: diff }>\text { 0) }\end{array}$ \\
\hline $\begin{array}{c}\text { Entrepreneurial } \\
\text { Intention }\end{array}$ & 5.065217 & 5.355072 & 0.2898551 & 0.2071 \\
\hline $\begin{array}{c}\text { Entrepreneurial } \\
\text { Attitude }\end{array}$ & 5.226087 & 5.130435 & -0.0956522 & 0.6286 \\
\hline $\begin{array}{c}\text { Entrepreneurial } \\
\text { Self-Efficacy }\end{array}$ & 4.428571 & 5.173913 & 0.7453416 & $0.0164{ }^{* *}$ \\
\hline $\begin{array}{c}\text { Entrepreneurial } \\
\text { Mindset }\end{array}$ & 5.289855 & 5.347826 & 0.057971 & 0.3970 \\
\hline $\begin{array}{c}\text { Core Self } \\
\text { Evaluation }\end{array}$ & 5.330435 & 5.608696 & 0.2782609 & 0.1555 \\
\hline Creativity & 5.054348 & 4.956522 & -0.0978261 & 0.6103 \\
\hline $\begin{array}{c}\text { Financial } \\
\text { Literacy }\end{array}$ & 3.768116 & 5.347826 & 1.57971 & $0.0000 * * *$ \\
\hline $\begin{array}{c}\text { Marshalling of } \\
\text { Resources }\end{array}$ & 4.826087 & 5.217391 & 0.3913043 & 0.1492 \\
\hline $\begin{array}{c}\text { Planning } \\
\text { Teamwork }\end{array}$ & 5.228261 & 6.086957 & 0.8586957 & $0.0014 * * *$ \\
\hline$* * * p<0.01, * * p<0.05, *<0.1$. & 5.913043 & -0.057971 & 0.6053 \\
\hline
\end{tabular}

Table A9. Output of $t$-tests on entrepreneurial characteristics, pre- and post-course, of the students who worked on entrepreneurial ideas proposed by other students.

\begin{tabular}{|c|c|c|c|c|}
\hline Variable & $\begin{array}{c}\text { Average Pre } \\
\text { CAST }\end{array}$ & $\begin{array}{l}\text { Average Post } \\
\text { CAST }\end{array}$ & $\begin{array}{c}\text { diff }=\text { avg post } \\
\text { CAST }- \\
\text { avg pre CAST } \\
(\text { Ho: diff }=0)\end{array}$ & $\begin{array}{c}p \text {-Value } \\
(\text { Ha: diff }>0)\end{array}$ \\
\hline $\begin{array}{l}\text { Entrepreneurial } \\
\text { Intention }\end{array}$ & 5.409091 & 5.590909 & 0.1818182 & 0.3619 \\
\hline $\begin{array}{c}\text { Entrepreneurial } \\
\text { Attitude }\end{array}$ & 5.872727 & 4.818182 & -1.054545 & 0.9934 \\
\hline $\begin{array}{c}\text { Entrepreneurial } \\
\text { Self-Efficacy }\end{array}$ & 4.909091 & 5.454545 & 0.5454545 & 0.1118 \\
\hline $\begin{array}{l}\text { Entrepreneurial } \\
\text { Mindset }\end{array}$ & 5.69697 & 6.090909 & 0.3939394 & 0.2198 \\
\hline $\begin{array}{l}\text { Core Self } \\
\text { Evaluation }\end{array}$ & 5.654545 & 5.727273 & 0.0727273 & 0.4430 \\
\hline Creativity & 5.840909 & 4.363636 & -1.477273 & 0.9945 \\
\hline $\begin{array}{l}\text { Financial } \\
\text { Literacy }\end{array}$ & 3.939394 & 5.727273 & 1.787879 & $0.0028^{* * *}$ \\
\hline $\begin{array}{l}\text { Marshalling of } \\
\text { Resources }\end{array}$ & 5.181818 & 5.818182 & 0.6363636 & 0.0503 * \\
\hline Planning & 5.840909 & 6.727273 & 0.8863636 & $0.0017^{* * *}$ \\
\hline Teamwork & 6.393939 & 6.484848 & 0.0909091 & 0.3605 \\
\hline
\end{tabular}




\section{Note}

1 Unite! is a university network for innovation, technology and engineering that has the aim of transforming higher education in Europe through multidisciplinary, multicultural and multilingual education, research and entrepreneurship. The aim of Unite! is to connect engineering, science and technology with important societal challenges and to provide skills for a new generation of European and global citizens through the combined work of university students, faculty members and staff.

\section{References}

Athayde, Rosemary. 2009. Measuring enterprise potential in young people. Entrepreneurship Theory and Practice 33: 481-500. [CrossRef]

Bae, Tae Jun, Shanshan Qian, Chao Miao, and James O. Fiet. 2014. The relationship between entrepreneurship education and entrepreneurial intentions: A meta-analytic review. Entrepreneurship Theory and Practice 38: 217-54. [CrossRef]

Barr, Steve, Ted Baker, Stephen Markham, and Angus Kingon. 2009. Bridging the Valley of Death: Lessons Learned from 14 Years of Commercialization of Technology Education. Academy of Management Learning $\mathcal{E}$ Education 8: 370-88. [CrossRef]

Bergmann, Heiko, Christian Hundt, and Rolf Sternberg. 2016. What makes student entrepreneurs? On the relevance (and irrelevance) of the university and the regional context for student start-ups. Small Business Economics 30: 334-43. [CrossRef]

Birtchnell, Thomas, Tillmann Böhme, and Robert Gorkin. 2017. 3D printing and the third mission: The university in the materialization of intellectual capital. Technological Forecasting and Social Change 123: 240-49. [CrossRef]

Boyd, Nancy G., and George S. Vozikis. 1994. The influence of self-efficacy on the development of entrepreneurial intentions and actions. Entrepreneurship Theory Practice 18: 63-77. [CrossRef]

Carree, Martin, Antonio Della Malva, and Enrico Santarelli. 2014. The contribution of universities to growth: Empirical evidence for Italy. Journal of Technology Transfer 39: 393-414. [CrossRef]

Cassia, Lucio, and Alessandra Colombelli. 2008. Do universities knowledge spillovers impact on new firm's growth? Empirical evidence from UK. International Entrepreneurship and Management Journal 4: 453-65. [CrossRef]

Charney, Alberta, and Gary Libecap. 2000. The Impact of Entrepreneurship Education: An Evaluation of the Berger Entrepreneurship Program at the University of Arizona, 1985-1999. Kansas City: Kauffman Centre for Entrepreneurial Leadership. [CrossRef]

Chen, Chao C., Patricia Gene Greene, and Ann Crick. 1998. Does entrepreneurial self-efficacy distinguish entrepreneurs from managers? Journal of Business Venturing 13: 295-316. [CrossRef]

Chiarello, Maria Assunta, Riccardo Fini, Silvia Ghiselli, Claudia Girotti, Azzurra Meoli, and Maurizio Sobrero. 2021. Student and Graduate Entrepreneurship in Italy_Report 2020. Available online: https:/ / papers.ssrn.com/sol3/papers.cfm?abstract_id=3774 909 (accessed on 18 January 2022).

Colombelli, Alessandra, Antonio De Marco, Emilio Paolucci, Riccardo Ricci, and Giuseppe Scellato. 2021a. University technology transfer and the evolution of regional specialization: The case of Turin. Journal of Technology Transfer 46: 933-60. [CrossRef]

Colombelli, Alessandra, Andrea Panelli, and Emilio Paolucci. 2021b. The implications of entrepreneurship education on the careers of PhDs: Evidence from the challenge-based learning approach. CERN IdeaSquare Journal of Experimental Innovation 5: 49-55. [CrossRef]

Colombelli, Alessandra, Shiva Loccisano, Andrea Panelli, Orazio A. M. Pennisi, and Francesco Serraino. 2022. Entrepreneurship Education: The Effects of Challenge-Based Learning on the Entrepreneurial Mindset of University Students. Administrative Sciences 12: 10. [CrossRef]

Dana, Leo Paul. 2001. Education and training of entrepreneurs in Asia. Education + Training 43: 405-16. [CrossRef]

Delmar, Frédéric, and Scott Shane. 2003. Does Business Planning Facilitate the Development of New Ventures? Strategic Management Journal 24: 1165-85. [CrossRef]

Dreisler, Poul, Per Blenker, and Kent Nielsen. 2003. Promoting entrepreneurship—Changing attitudes or behaviour? Journal of Small Business and Enterprise Development 10: 383-93. [CrossRef]

Duval-Couetil, Nathalie. 2013. Assessing the impact of entrepreneurship education programs: Challenges and approaches. Journal of Small Business Management 51: 394-409. [CrossRef]

Duval-Couetil, Nathalie, Michael Ladisch, and Soohyun Yi. 2021. Addressing academic researcher priorities through science and technology entrepreneurship education. Journal of Technology Transfer 46: 288-318. [CrossRef]

European Commission. 2012. Effects and Impact of Entrepreneurship Programmes in Higher Education. Available online: https: / / ec.europa.eu/docsroom/documents/375/attachments/1/translations (accessed on 18 January 2022).

Fayolle, Alain, and Benoit Gailly. 2015. The impact of entrepreneurship education on entrepreneurial attitudes and intention: Hysteresis and persistence. Journal of Small Business Management 53: 75-93. [CrossRef]

Fayolle, Alain, Benoit Gailly, and Narjisse Lassas-Clerc. 2006. Assessing the impact of entrepreneurship education programmes: A new methodology. Journal of European Industrial Training 30: 701-20. [CrossRef]

Foss, Nicolai, and Peter Klein. 2012. Organizing Entrepreneurial Judgment: A New Approach to the Firm. Cambridge: Cambridge University Press. [CrossRef]

Fullerton, Rosemary R., and Cheryl S. McWatters. 2001. Production performance benefits from JIT implementation. Journal of Operations Management 19: 81-96. [CrossRef]

George, Jennifer M., and Jing Zhou. 2001. When Openness to Experience and Conscientiousness are Related to Creative Behavior: An Interactional Approach. Journal of Applied Psychology 86: 687-97. [CrossRef] 
Gibb, Allan. 2002. In pursuit of a new enterprise and entrepreneurship paradigm for learning: Creative destruction, new values, new ways of doing things and new combinations of knowledge. International Journal of Management Reviews 4: 213-32. [CrossRef]

Gielnik, Michael M., Michael Frese, Audrey Kahara-Kawuki, Isaac Wasswa Katono, Sarah Kyejjusa, Muhammed Ngoma, John Munene, Rebecca Namatovu-Dawa, Florence Nansubuga, Laura Orobia, and et al. 2015. Action and action-regulation in entrepreneurship: Evaluating a student training for promoting entrepreneurship. Academy of Management Learning E Education 14: 69-94. [CrossRef]

Gould, Julie. 2015. How to build a better PhD. Nature 528: 22-25. [CrossRef] [PubMed]

Hahn, Davide, Tommaso Minola, Giulio Bosio, and Lucio Cassia. 2020. The impact of entrepreneurship education on university students' entrepreneurial skills: A family embeddedness perspective. Small Business Economics 55: 257-82. [CrossRef]

Handscombe, Robert, Elena Rodriguez-Falcon, and Eann Patterson. 2007. Embedding Enterprise in Science and Engineering Departments. Education + Training 50: 615-25. [CrossRef]

Henry, Colette. 2004. The effectiveness of training for new business creation: A longitudinal study. International Small Journal 22: 249-71. [CrossRef]

Hills, Gerald E. 1988. Variations in university entrepreneurship education: An empirical study and an evolving field. Journal of Business Venturing 3: 109-22. [CrossRef]

Honig, Benson. 2004. Entrepreneurship education: Toward a model of contingency-based business planning. Academy of Management Learning E Education 3: 258-73. [CrossRef]

Hoppe, Magnus. 2015. Policy and entrepreneurship education. Small Business Economics 46: 13-29. [CrossRef]

Hynes, Briga. 1996. Entrepreneurship education and training-Introducing entrepreneurship into non-business disciplines. Journal of European Industrial Training 20: 10-17. [CrossRef]

Judge, Timothy A., Amir Erez, Joyce E. Bono, and Carl J. Thoresen. 2003. The Core Self-Evaluations Scale: Development of a measure. Personnel Psychology 56: 303-31. [CrossRef]

Kassean, Hemant, Jeff Vanevenhoven, Eric Liguori, and Doan E. Winkel. 2015. Entrepreneurship education: A need for reflection, real-world experience and action. International Journal of Entrepreneurial Behavior \& Research 21: 690-708. [CrossRef]

Kirzner, Israel. 1997. Entrepreneurial discovery and the competitive market process: An Austrian approach. Journal of Economic Literature 35: 60-85. Available online: https://www.jstor.org/stable/ 40229553 (accessed on 18 January 2022).

Kuratko, Donald F. 2005. The emergence of entrepreneurship education: Development, Trends and Challenges. Entrepreneurship Theory and Practice 29: 577-98. [CrossRef]

Larsson, Johan P., Karl Wennberg, Johan Wiklund, and Mike Wright. 2017. Location choices of graduate entrepreneurs. Research Policy 46: 1490-504. [CrossRef]

Lee, Sang M., Seong-bae Lim, Raghuvar D. Pathak, Daesung Chang, and Weixing Li. 2006. Influences on students' attitudes towards entrepreneurship: A multi-country study. The International Entrepreneurship and Management Journal 2: 351-66. [CrossRef]

Linán, Francisco, and Yi-Wen Chen. 2009. Development and Cross-Cultural Application of a Specific Instrument to Measure Entrepreneurial Intentions. Entrepreneurship Theory and Practice 33: 593-617. [CrossRef]

Lyons, Elizabeth, and Laurina Zhang. 2018. Who does (not) benefit from entrepreneurship programs? Strategic Management Journal 39: 85-112. [CrossRef]

Martin, Bruce C., Jeffrey J. McNally, and Michael J. Kay. 2013. Examining the formation of human capital in entrepreneurship: A meta-analysis of entrepreneurship education outcomes. Journal of Business Venturing 28: 211-24. [CrossRef]

Matley, Harry. 2006. Researching entrepreneurship and education, Part 2: What is entrepreneurship and does it matter? Education + Training 48: 704-18. [CrossRef]

Matthews, Charles, and Susanne Scott. 1995. Uncertainty and planning in small and entrepreneurial firms: An empirical assessment. Journal of Small Business Management 33: 34-52.

McGee, Jeffrey E., Mark Peterson, Stephen Mueller, and Jennifer M. Sequeira. 2009. Entrepreneurial Self-Efficacy: Refining the Measure. Entrepreneurship Theory and Practice 33: 965-88. [CrossRef]

McGrath, Rita, and Ian MacMillan. 2000. Discovery Driven Planning. Boston: Harvard Business School Press.

McKeown, Julie, Cindy Millman, Srikanth Reddy Sursani, Kelly Smith, and Lynn M. Martin. 2006. Graduate entrepreneurship education in the United Kingdom. Education + Training 48: 597-613. [CrossRef]

McMullan, W. Ed, and Wayne A. Long. 1987. Entrepreneurship education in the nineties. Journal of Business Venturing 2: 261-75. [CrossRef]

Minola, Tommaso, Davide Donina, and Michele Meoli. 2016. Students climbing the entrepreneurial ladder: Does university internationalization pay off? Small Business Economics 47: 565-87. [CrossRef]

Moberg, Kåre, Lene Vestergaard, Alain Fayolle, Dana Redford, Thomas Cooney, Slavica Singer, Klaus Sailer, and Diana Filip. 2014. How to Assess and Evaluate the Influence of Entrepreneurship Education. ASTEE Project. Odense: The Danish Foundation for Entrepreneurship-Young Enterprise, ISBN 978-87-90386-06-1.

Moriano, Juan A., Marjan Gorgievski, Mariola Laguna, Ute Stephan, and Kiumars Zarafshani. 2012. A cross cultural approach to understanding entrepreneurial intention. Journal of Career Development 39: 162-85. [CrossRef]

Morris, Michael H., Justin W. Webb, Jun Fu, and Sujata Singhal. 2013. A competency-based perspective on entrepreneurship education: Conceptual and empirical insights. Journal of Small Business Management 51: 352-69. [CrossRef]

Mwasalwiba, Ernest Samwel. 2010. Entrepreneurship education: A review of its objectives, teaching methods, and impact indicators. Education + Training 52: 20-47. [CrossRef] 
Nabi, Ghulam, Francisco Liñán, Alain Fayolle, Norris Krueger, and Andreas Walmsley. 2017. The impact of entrepreneurship education in higher education: A systematic review and research agenda. Academy of Management Learning E Education 16: 277-99. [CrossRef]

Nunnally, Jum. 1978. Psychometric Theory. New York: McGraw-Hill.

Oggero, Noemi, Maria Cristina Rossi, and Elisa Ughetto. 2019. Entrepreneurial spirits in women and men. The role of financial literacy and digital skills. Small Business Economics 55: 313-27. [CrossRef]

Peterman, Nicole, and Jessica Kennedy. 2003. Enterprise education: Influencing students' perception of entrepreneurship. Entrepreneurship Theory and Practice 28: 129-44. [CrossRef]

Pittaway, Luke. 2009. The role of inquiry-based learning in entrepreneurship education. Industry and Higher Education 23: 153-62. [CrossRef]

Pittaway, Luke, and Jason Cope. 2007. Simulating Entrepreneurial Learning: Assessing the Utility of Experiential Learning Designs. Management Learning 38: 211-33. [CrossRef]

Pittaway, Luke, and Paul Hannon. 2008. Institutional strategies for developing enterprise education: A conceptual analysis. Journal of Small Business and Enterprise Development 15: 202-26. [CrossRef]

Rae, David, and Mary Carswell. 2000. Using a life-story approach in entrepreneurial learning: The development of a conceptual model and its implications in the design of learning experiences. Education and Training 42: 220-27. [CrossRef]

Ramos-Rodríguez, Antonio Rafael, José Aurelio Medina-Garrido, and José Ruiz-Navarro. 2019. Why not now? Intended timing in entrepreneurial intentions. International Entrepreneurship Management Journal 15: 1221-46. [CrossRef]

Rasmussen, Einar A., and Roger Sørheim. 2006. Action-based entrepreneurship education. Technovation 26: 185-94. [CrossRef]

Ricci, Riccardo, Alessandra Colombelli, and Emilio Paolucci. 2019. Entrepreneurial activities and models of advanced European science and technology universities. Management Decision 57: 3447-72. [CrossRef]

Rosa, Peter. 2003. Hardly likely to make the Japanese tremble. International Small Business Journal 12: 435-57. [CrossRef]

Sánchez, José C. 2011. University training for entrepreneurial competencies: Its impact on intention of venture creation. International Entrepreneurship and Management Journal 7: 239-54. [CrossRef]

Sánchez, José C. 2013. The impact of an entrepreneurship education program on entrepreneurial competencies and intention. Journal of Small Business Management 51: 447-65. [CrossRef]

Shahab, Yasir, Ye Chengang, Angel David Arbizu, and Muhammad Jamal Haider. 2019. Entrepreneurial self-efficacy and intention: Do entrepreneurial creativity and education matter? International Journal of Entrepreneurial Behavior E Research 25: 259-80. [CrossRef]

Siegel, Donald S., and Mike Wright. 2015. Academic entrepreneurship: Time for a rethink? British Journal of Management 26: 582-95. [CrossRef]

Solomon, George T., Susan Duffy, and Ayman Tarabishy. 2002. The state of entrepreneurship education in the United States: A national survey overview. International Journal of Entrepreneurship Education 1: 65-86.

Souitaris, Vangelis, Stefania Zerbinati, and Andreas Al-Laham. 2007. Do entrepreneurship programmes raise entrepreneurial intention of science and engineering students? The effect of learning, inspiration and resources. Journal of Business Venturing 22 : 566-91. [CrossRef]

Thurik, Roy, and Sander Wennekers. 2004. Entrepreneurship, small business and economic growth. Journal of Small Business and Enterprise Development 11: 140-49. [CrossRef]

Thursby, Marie C., Anne W. Fuller, and Jerry Thursby. 2009. An integrated approach to educating professionals for careers in innovation. Academy of Management Learning and Education 8: 389-406. [CrossRef]

Truell, Allen D., Linda Webster, and Conda Davidson. 1998. Fostering entrepreneurial spirit: Integrating the business community into the classroom. Business Education Forum 53: 28-29.

Varano, Mirko, Elina Kähkönen, H. Aarnio, Maria Clavert, Matti Kaulio, Kent Thorén, Alessandra Colombelli, Giuliano Sansone, Elisabetta Raguseo, Emilio Paolucci, and et al. 2018. Entrepreneurship education ecosystems in engineering and technology (E4T). Paper presented at 46th SEFI Annual Conference 2018, Copenhagen, Denmark, September 17-21.

Veciana, José, Marinés Aponte, and David Urbano. 2005. University students' attitudes towards entrepreneurship: A two country comparison. International Entrepreneurship and Management Journal 1: 165-82. [CrossRef]

Vesper, Karl, and William Gartner. 1997. Measuring progress in entrepreneurship education. Journal of Business Venturing 12: 403-21. [CrossRef]

Vesper, Karl H., and W. Ed McMullen. 1988. Entrepreneurship: Today courses, tomorrow degrees? Entrepreneurship Theory and Practice 13: 7-13. [CrossRef]

Walter, Sascha G., Praveen K. Parboteeah, and Achim Walter. 2013. University Departments and Self-Employment Intentions of Business Students: A Cross-Level Analysis. Entrepreneurship Theory and Practice 37: 175-200. [CrossRef]

Wenninger, Helena. 2018. Student Assessment of Venture Creation Courses in Entrepreneurship Higher Education-An Interdisciplinary Literature Review and Practical Case Analysis. Entrepreneurship Education and Pedagogy 2: 58-81. [CrossRef]

West, Michael A. 2003. Innovation implementation in work teams. In Group Creativity: Innovation through Collaboration. Edited by Paul B. Paulus and Bernard A. Nijstad. Oxford: Oxford University Press, pp. 245-76. [CrossRef]

Wilson, Fiona, Jill Kickul, and Deborah Marlino. 2007. Gender entrepreneurial self-efficacy, and entrepreneurial career intentions: Implications for entrepreneurship education. Entrepreneurship Theory and Practice 31: 387-406. [CrossRef]

Wright, Mike, Donald S. Siegel, and Philippe Mustar. 2017. An emerging ecosystem for student start-ups. Journal of Technology Transfer 42: 909-22. [CrossRef] 
Zahra, Shaker A., and Gerard George. 2002. Absorptive Capacity: A Review, Reconceptualization, and Extension. The Academy of Management Review 27: 185-203. [CrossRef]

Zhang, Ying, Geert Duysters, and Myriam Cloodt. 2014. The role of entrepreneurship education as a predictor of university students' entrepreneurial intention. International Entrepreneurship and Management Journal 10: 623-41. [CrossRef]

Zhao, Hao, Scott Seibert, and Gerald E. Hills. 2005. The mediating role of self-efficacy in the development of entrepreneurial intentions. Journal of Applied Psychology 90: 1265-72. [CrossRef] [PubMed] 